\title{
Composition of the noble gases in Canyon Diablo
}

\author{
R. G. DownING* and O. K. MANUEL \\ Department of Chemistry, University of Missouri, Rolla, MO 65401 U.S.A.
}

(Received March 10, 1982: Accepted June 23, 1982)

Five separate fractions of noble gases were extracted and analyzed as a $150 \mathrm{~g}$ sample of the Canyon Diablo iron meteorite was heated to successively higher temperatures by direct coupling with an RF coil. Isotopic compositions of the light gases, $\mathrm{He}, \mathrm{Ne}$ and $\mathrm{Ar}$, demonstrate that essentially their entire inventory was produced by spallation reactions. Spallation products are also a prominent feature of the isotopes of $\mathrm{Kr}$ and $\mathrm{Xe}$, but in each gas fraction the spallogenic heavy gases were mixed with a nonspallogenic component. The isotopic composition of $\mathrm{Kr}$ and Xe trapped in Canyon Diablo are shown to be type-Y, rather than the type- $\mathrm{X} \mathrm{Kr}$ and $\mathrm{Xe}$ that is found with planetary $\mathrm{He}$ and $\mathrm{Ne}$ in mildly oxidized carbon fractions of chondrites.

Large variations are observed in ratios of the light spallogenic noble gases. Spallation products in $\mathrm{Kr}$ and $\mathrm{Xe}$ tend to correlate with those in $\mathrm{Ne}$, rather than in $\mathrm{Ar}$, suggesting that diffusive fractionation is not responsible for variations in the ${ }^{21} \mathrm{Ne} /{ }^{38} \mathrm{Ar}$ ratio. It is suggested that portions of the material in Canyon Diablo may have been preirradiated.

Xenon contains a large component of excess ${ }^{129} \mathrm{Xe}$ and ${ }^{131} \mathrm{Xe}$ from neutron capture on $\mathrm{Te}$ at energies above $0.4 \mathrm{ev}$, but there is no indication that the decay of primordial ${ }^{129} \mathrm{I}$ or the incorporation of exotic interstellar dust produced the excess ${ }^{129} \mathrm{Xe}$ or ${ }^{131} \mathrm{Xe}$ in our sample of Canyon Diablo. The maximum amount of excess ${ }^{136} \mathrm{Xe}$ in our sample from fission of the hypothetical superheavy elements is shown to be 600 atoms/g if the trapped Xe is atmospheric in composition; however, if the trapped Xe is AVCC, it might be as high as 6,000 atoms/g.

\section{INTRODUCTION}

The noble gas isotopes in iron meteorites contain a relatively large component of spallation products generated by cosmic-ray bombardment. Elemental and isotopic abundances of spallogenic noble gases in iron meteorites have been the subject of many investigations since PANETH et al. (1952) first reported the presence of spallogenic ${ }^{3} \mathrm{He}$ in meteorites. Measurements of spallogenic $\mathrm{He}, \mathrm{Ne}$ and $\mathrm{Ar}$ in iron meteorites (EBERT and WäNKE, 1957; VINOGRADOV et al., 1957; HoFFMAN and Nier, 1958, 1959; FireMAN, 1958; GERLING and LEVSKII, 1958; SIGNER and NIER, 1960, 1962; SCHAEFFE R and ZÄHRINGER, 1960; SCHAEFFER and FISHER, 1960; HEYMANN et al., 1966; NYQUIST et al., 1967, 1972, 1973; HinTENBERGER et al., 1969; SCHULTZ et al., 1969, 1971) are combined with measurements of cosmic-ray produced radioactivities in iron meteorites (ARNOLD et al., 1961; LIPSCHTZ et al., 1965; SCHAEFFER and HeYMANN, 1965) to obtain information about the length of time that bodies were exposed to cosmic rays, the preatmospheric size of the meteoroids, the energy spectrum of cosmic ray primaries and the attenuation of primary and secondary cosmic ray particles in matter. The same type of information has been obtained from analyses of spallation products in stone meteorites (CRESSEY and BOGARD, 1976; FINKEL et al., 1978; MüLLER et al., 1981 and references therein).

Although quantitative formulation of spallation yields as a function of cosmic ray energy and mass number of the target nuclei is complex (GeIss et al., 1962; RudSTAM, 1966; SchWARZ

*Present address: National Bureau of Standards, B-108, Building 235, Washington, DC 20234, U.S.A. 
and Oeschger, 1967), the spallogenic noble gases in a typical iron meteorite specimen contain a surprisingly simple record of exposure to cosmic rays for a period of about $10^{9} \mathrm{yrs}$ (KIRSTEN, 1976) while buried at a depth of about $10-40 \mathrm{~cm}$ (SigNer and NiER, 1962; HoNDA, 1962; SCHUlTZ et al., 1971). By comparison, the spallogenic noble gases in a typical stone meteorite specimen are reported to show an exposure to cosmic rays of higher energy (NYQUIST et al., 1973) for a period of $\approx 10^{7} \mathrm{yrs}$ (KIRSTEN, 1976). We will show that the cosmic ray exposure history of the sample analyzed in this study is more complex than indicated by these generalities.

Spallogenic $\mathrm{Kr}$ and $\mathrm{Xe}$ have been reported in a few iron meteorites (MuNK, 1967a, b), and a few recent studies of these two heavy noble gases in iron meteorites have a attempted to identify the isotopic composition of $\mathrm{Kr}$ and $\mathrm{Xe}$ initially trapped there (HENNECKE and MANUEL, 1977; Palma and Heymann, 1980). Although the extremely low levels of trapped noble gases in iron meteorites make this a formidable experimental problem, the results are expected to provide important new constraints on the chemical and isotopic abundances of noble gases in the region of the primitive nebula sampled by iron meteorites.

The realization that minerals within stone meteorites trapped two, chemically and isotopically distinct types of planetary noble gases (MANUEL and SABU, 1975; SABU and MANUEL, 1980a) provided impetus for the effort to obtain information on the isotopic compositions of heavy noble gases trapped in iron meteorites. One of the noble gas components in stone meteorites, type- $\mathrm{X}$ gases, contains all five stable elements but isotopic ratios of the $\mathrm{Kr}$ and $\mathrm{Xe}$ in this componente differ by as much as a factor of two from those in air (NIER, 1950b) or in bulk chondrites (EUGSTER et al., 1967). The other component, type-Y gases, contains only $\mathrm{Ar}, \mathrm{Kr}$ and Xe. Type-Y gases account for the bulk of the $\mathrm{Ar}, \mathrm{Kr}$ and $\mathrm{Xe}$ in chondrites and for essentially all of the heavy noble gases in ureilites (WILKENING and MARTI, 1976) and in the ter- restrial planets (MANUEL and SABU, 1981). Type-X gases account for all of the $\mathrm{He}$ and $\mathrm{Ne}$, but only a small fraction of the $\mathrm{Ar}, \mathrm{Kr}$ and $\mathrm{Xe}$, trapped in chondrites. Information on the isotopic composition of $\mathrm{Kr}$ and $\mathrm{Xe}$ trapped in iron meteorites would thus indicate the type of noble gas reservoir in the region of nebula where these bodies formed.

Isotopic analyses of noble gases in iron meteorites are also of interest in providing information on the value of the indigenous ${ }^{40} \mathrm{Ar} /{ }^{36} \mathrm{Ar}$ ratio (HENNECKE and MANUEL, 1977; Fisher, 1981) and in setting upper limits on the amounts of siderophilic superheavy elements (SHE) in the early solar system (NozETTE and BoYnTON, 1981). The possible trapping of SHE in iron meteorites is unresolved (BULL, 1979; RUNCORN et al., 1980), although continued reports of noble gas evidence for volatile superheavy elements in the Allende meteorite (ANDERS, 1981) are cast in doubt by continued failure to deal with significant parts of the experimental observations, e.g., the ubiquitous correlation of excess ${ }^{136} \mathrm{Xe}$ with $\mathrm{He}$ and $\mathrm{Ne}$ (MANuEl and Sabu, 1975; Sabu and Manuel, 1980a).

\section{EXPERIMENTAL Procedures}

In most earlier measurements of noble gases in iron meteorites, the gases were released from a sample, typically weighing $0.1-1 \mathrm{~g}$, by a single stage melting of the sample in a heated crucible (e.g., Signer and NiER, 1960, 1962; HeYMANN et al., 1966; SchulTZ et al., 1969, 1971; NYQUIST et al., 1967, 1972). In this work, the gases were instead extracted from a $150 \mathrm{~g}$ sample by stepwise heating. To avoid fluxing of the crucible with molten iron, the sample was heated directly by R. F. induction. Molten drippings from the sample were collected in a previously degassed crucible. A similar technique was used by LÄMMERZAHL and ZÄHRINGER (1966) to measure the spallation yields of $\mathrm{Ar}$ in iron meteorites.

The sample used in this study was from a specimen of Canyon Diablo that had been 
purchased in 1967 from the American Meteorite Laboratory (AML \# 34.6099). The specimen was a cut slab, $\approx 11 \mathrm{~cm} \times 9 \mathrm{~cm} \times 1.3 \mathrm{~cm}$, containing large inclusions of graphite and troilite, usually rimmed with schreibersite. Several small inclusions of schreibersite were also visible on the polished surfaces, and an oxidized crust skirted all uncut surfaces. GLENN Huss (private communication, 1981) stated that the specimen was collected on the "plains", about $2.4 \mathrm{~km}$ from the rim of the Meteor Crater, Arizona. He suggests that this specimen would probably be classified as only lightly shocked in the classification scheme of HEYMANN et al. (1966).

The sample, $\approx 9 \mathrm{~cm} \times 1.75 \mathrm{~cm} \times 1.25 \mathrm{~cm}$, was cut with a continuous band saw from a region showing no surface inclusions. The area of abrasion was cooled with a stream of air, and cutting was suspended whenever the temperature of the sample became perceptibly warm. The resultant sample was removed from any visible inclusion or oxidized surface by at least $5 \mathrm{~mm}$. A small hole, diameter $\approx 2 \mathrm{~mm}$, was drilled about $7 \mathrm{~mm}$ from one end. It was then repeatedly scrubbed in a $1: 1 \mathrm{HNO}_{3}$ solution to remove surface contamination, rinsed in copious amounts of water and dried. About $3.2 \mathrm{~g}$ was etched away by the above scrubbing, and the final sample weight was $148.9785 \mathrm{~g}$.

The sample was suspended on a $2 \mathrm{~mm}$ tungsten wire, about $10 \mathrm{~cm}$ above a large molybdenum crucible, in a water-cooled extraction bottle fabricated of quartz. The extraction system, including the sample, was baked overnight at about $200^{\circ} \mathrm{C}$. The molybdenum crucible was repeatedly degassed at $1,600^{\circ} \mathrm{C}$ until the system blank reached an acceptable level, taking a total degassing period of $\approx 3.5 \mathrm{hr}$. The sample was probably further heated by radiation from the hot molybdenum crucible at this time, but the temperature of the sample was not measured. There was no visible radiation from the sample; its temperature clearly remained below the $750^{\circ} \mathrm{C}$ detection limit of the optical pyrometer.

For the extraction of gases from the sample, the R.F. coil was raised so that the sample itself was heated directly by induction. The gases were extracted and analyzed as five separate fractions. For the first fraction, the sample was heated to $800^{\circ} \mathrm{C}$. It was heated to $1,200^{\circ} \mathrm{C}$ to release the second gas fraction. The third gas fraction was released as the bottom section ( $\approx$ one-third) of the sample melted and dripped into the cool molybdenum crucible. The induction coil was raised to melt off the middle section ( $\approx$ one-fourth) of the sample and release the next gas fraction. The fifth and final gas fraction was released as the rest of the meteorite melted and dripped into the molybdenum crucible.

The sample drippings did not flux the crucible walls, and it was found at the end of the experiment that the cooled iron did not adhere to the molybdenum crucible. The material was dumped from the crucible, weighed, and found to contain all but $2.130 \mathrm{~g}$ of the original sample. The walls of the quartz extraction bottle were considerably darkened by vapor deposition during gas extraction, and the material deposited there would presumably account for the bulk of the mass loss.

The melting process was much like that seen in the melting of an ice cube. Molten material formed on the surface of the section being heated, moved downward over the surface, and then dripped from the sample at a rate of about one drop per $\approx 5$ seconds. Only small droplets were observed falling from the main sample mass during the melting steps. At no time during the experiment was there any indication of unmelted material falling from the sample, and subsequent examination of the material in the crucible showed no evidence of unmelted sample. There was some alloying of the tungsten wire with molten sample, but only over the length of the wire directly supporting the sample, $\approx 1.3 \mathrm{~cm}$. At the end of the experiment there appeared to be no sample adhering to the tungsten wire.

The evolved gases were first scrubbed on a Ti-Zr getter at $850^{\circ} \mathrm{C}$ for 30 minutes. After the getter had cooled, the gases were transferred to a secondary clean-up system where the gases 
werè cleaned a second time on another $\mathrm{Ti}-\mathrm{Zr}$ getter at $850^{\circ} \mathrm{C}$. The gases were released from charcoal as four spearate fractions for analysis in a mass spectrometer (REYNOLDS, 1956) operating in the static mode $-\mathrm{He}$ and $\mathrm{Ne}$, then $\mathrm{Ar}$, next $\mathrm{Kr}$ and finally $\mathrm{Xe}$.

The basic procedure used for analysis and data reduction are described by ALEXANDER (1970) and in subsequent papers from this laboratory. The sensitivity and mass discrimination of the mass spectrometer were determined by analysis of metered volumes of the artificial "Kaiser" gas mixture used in Reynolds' laboratory (FRICK, 1977). Air spikes containing about 0.01 ccSTP air were also analyzed as a crosscheck.

\section{RESUlTS AND DisCUSSION}

The results of these analyses are presented in Tables 1-3. The values tabulated there have been corrected for mass discrimination of the spectrometer and for system blanks and interferences. The quoted errors $(1 \sigma)$ on isotopic ratios include statistical errors from the mass spectrometric analysis and uncertainties in blanks, interferences and mass discrimination. Since isotopic ratios for the gases from Canyon Diablo are unlike those in air or in the system, background errors can be negligible for one isotope of a noble gas but very large for another isotope of the same gas, e.g., background errors on ${ }^{38} \mathrm{Ar}$ and ${ }^{40} \mathrm{Ar}$ in the 3rd melt fraction of Canyon Diablo. Under such conditions, SABU and MANUEL (1980b) note that it is not meaningful to report background errors for only one isotope of the gas. For this reason, typical and maximum values for background errors are shown in the tables as percentages of the ion current at each value of $\mathrm{e} / \mathrm{m}$. From sensitivity calibrations of the mass spectrometer with air pipettes and air spikes, the amounts shown in these tables for the reference isotope contain intralaboratory uncertainties estimated at $3 \%$ for ${ }^{3} \mathrm{He},{ }^{22} \mathrm{Ne}$ and ${ }^{132} \mathrm{Xe}$ and $6 \%$ for ${ }^{36} \mathrm{Ar}$ and ${ }^{84} \mathrm{Kr}$. For interlaboratory comparisons, an additional error of $20 \%$ should be allowed.
In addition to these uncertainties, it should be noted that the total gas contents shown in Tables 1-3 may include fractionation effects if the sample contained more gas than that analyzed by our procedure. Systematically low values for concentrations of the light gases would be generated if these preferentially escaped during preliminary heating of the extraction system, the sample and the crucible. Alternately, systematically low values for heavy gases might result if these were preferentially retained in the molten material as gases were collected for analysis. The possibility of residual gases in the drippings was not examined for fear that heating the crucible to melt about $150 \mathrm{~g}$ of iron might cause alloying and complete melting of the crucible too.

Fractionation effects in elemental or isotopic ratios seem unlikely, however, even if the total gas in the sample is somewhat higher than the value shown in Table 1-3. The amount of spallogenic ${ }^{3} \mathrm{He}$ in our sample is about midway in the range of values reported earlier for 56 different specimens of Canyon Diablo (HEYMANN et al., 1966), and NYQUIST et al. (1972) report that virtually no fractionation of spallogenic $\mathrm{He}, \mathrm{Ne}, \mathrm{Ar}$ or their isotopes occurred in the stepwise extraction of these gases from the Carbo-iron meteorite.

Spallogenic ${ }^{3} \mathrm{He},{ }^{21} \mathrm{Ne}$ and ${ }^{38} \mathrm{Ar} \quad$ Concentrations of major spallation and neutron-capture products in Canyon Diablo's noble gases are shown in Table 4, together with the results of a few earlier analyses of spallogenic noble gases in Canyon Diablo and other iron meteorites. Trapped gases account for a negligible fraction of the ${ }^{3} \mathrm{He},{ }^{21} \mathrm{Ne}$ and ${ }^{38} \mathrm{Ar}$ released from Canyon Diablo; the values tabulated in Table 4 for the three light noble gases therefore contain no corrections for trapped components. Significant amounts of the spallation-free isotopes of $\mathrm{Kr}$ and $\mathrm{Xe}$ were released in each of the Canyon Diablo gas fractions. The values tabulated in Table 4 for the two heavy noble gases have been corrected for a trapped component by assuming that the ${ }^{86} \mathrm{Kr}$ and ${ }^{136} \mathrm{Xe}$ are spallation-free and 


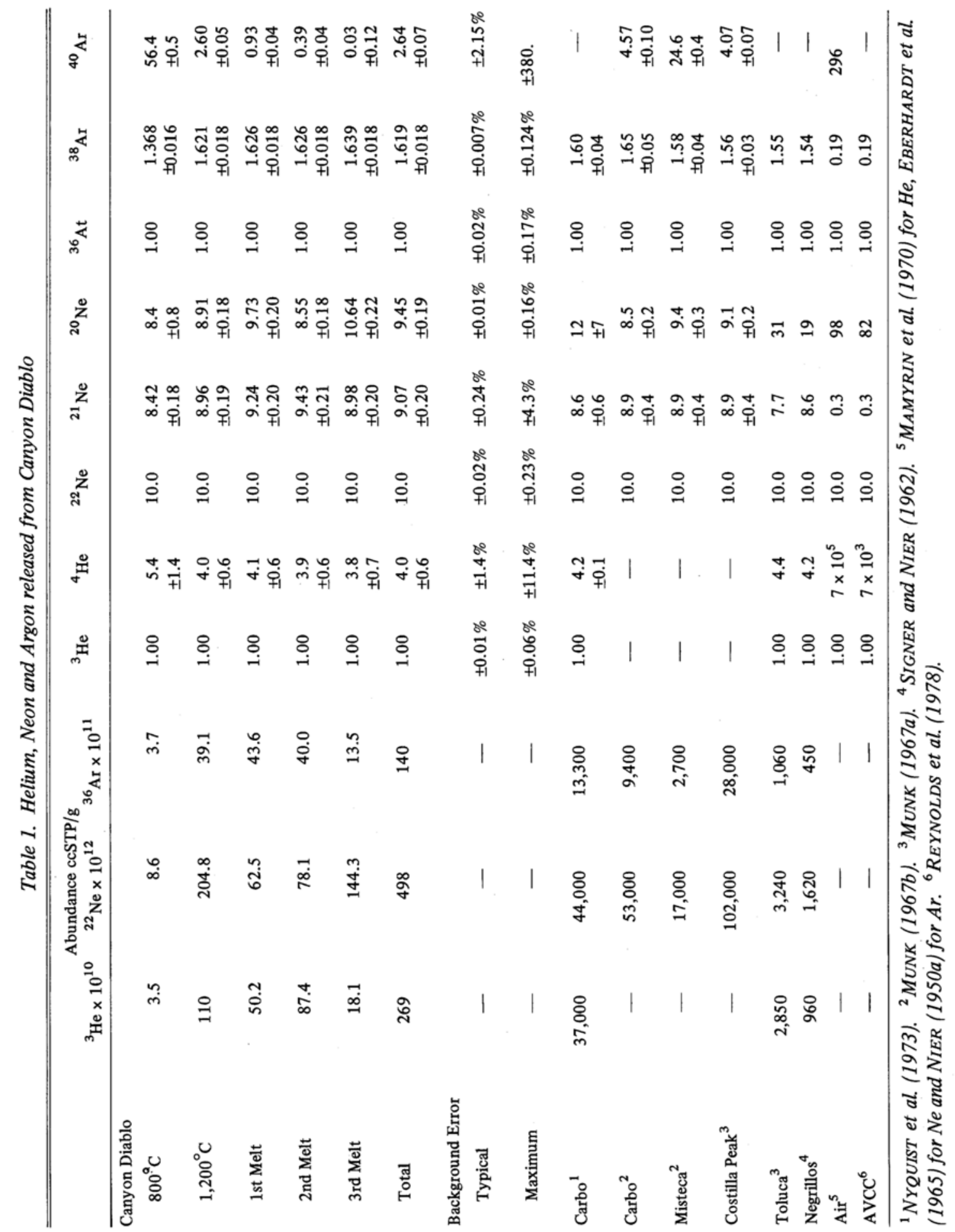


Table 2. Krypton released from Canyon Diablo

\begin{tabular}{|c|c|c|c|c|c|c|c|}
\hline & \multirow{2}{*}{$\begin{array}{c}\text { Abundance } \\
{ }^{84} \mathrm{Kr} \times 10^{15} \\
\mathrm{ccSTP} / \mathrm{g}\end{array}$} & \multirow[b]{2}{*}{${ }^{78} \mathrm{Kr}$} & \multirow[b]{2}{*}{${ }^{80} \mathrm{Kr}$} & \multicolumn{2}{|c|}{ Isotope Ratios } & \multirow[b]{2}{*}{${ }^{84} \mathrm{Kr}$} & \multirow[b]{2}{*}{${ }^{86} \mathrm{Kr}$} \\
\hline & & & & ${ }^{82} \mathrm{Kr}$ & ${ }^{83} \mathrm{Kr}$ & & \\
\hline \multicolumn{8}{|l|}{ Canyon Diablo } \\
\hline $800^{\circ} \mathrm{C}$ & 59.1 & $\begin{array}{r}0.83 \\
\pm 0.19\end{array}$ & $\begin{array}{r}4.78 \\
\pm 0.11\end{array}$ & $\begin{array}{l}21.8 \\
\pm 0.5\end{array}$ & $\begin{array}{l}21.3 \\
\pm 0.5\end{array}$ & 100.00 & $\begin{array}{l}30.1 \\
\pm 0.5\end{array}$ \\
\hline $1,200^{\circ} \mathrm{C}$ & 40.3 & $\begin{array}{r}9.97 \\
\pm 0.35\end{array}$ & $\begin{array}{l}20.7 \\
\pm 0.3\end{array}$ & $\begin{array}{l}43.5 \\
\pm 0.8\end{array}$ & $\begin{array}{l}48.3 \\
\pm 1.0\end{array}$ & 100.00 & $\begin{array}{l}29.4 \\
\pm 0.6\end{array}$ \\
\hline 1st Melt & 11.8 & $\begin{array}{l}16.7 \\
\pm 0.8\end{array}$ & $\begin{array}{l}34.7 \\
\pm 0.7\end{array}$ & $\begin{array}{l}59.8 \\
\pm 1.9\end{array}$ & $\begin{array}{r}67.9 \\
\pm 2.0\end{array}$ & 100.00 & $\begin{array}{l}28.9 \\
\pm 1.1\end{array}$ \\
\hline 2nd Melt & 4.3 & $\begin{array}{l}43.0 \\
\pm 4.9\end{array}$ & $\begin{array}{l}90.5 \\
\pm 5.9\end{array}$ & $\begin{array}{l}133 \\
\pm 10\end{array}$ & $\begin{array}{l}150 \\
\pm 11\end{array}$ & 100.00 & $\begin{array}{l}26.8 \\
\pm 2.7\end{array}$ \\
\hline 3rd Melt & 23.0 & $\begin{array}{l}24.0 \\
\pm 0.6\end{array}$ & $\begin{array}{l}51.1 \\
\pm 1.0\end{array}$ & $\begin{array}{l}78.2 \\
\pm 1.5\end{array}$ & $\begin{array}{l}89.8 \\
\pm 1.5\end{array}$ & 100.00 & $\begin{array}{l}27.4 \\
\pm 0.7\end{array}$ \\
\hline Total & 138.5 & $\begin{array}{l}10.0 \\
\pm 0.5\end{array}$ & $\begin{array}{l}22.3 \\
\pm 0.5\end{array}$ & $\begin{array}{l}44.2 \\
\pm 1.1\end{array}$ & $\begin{array}{l}48.5 \\
\pm 1.3\end{array}$ & 100.00 & $\begin{array}{l}29.3 \\
\pm 0.7\end{array}$ \\
\hline \multicolumn{8}{|c|}{ Background Error } \\
\hline Typical & - & $\pm 3.8 \%$ & $\pm 1.1 \%$ & $\pm 1.1 \%$ & $\pm 1.1 \%$ & $\pm 0.52 \%$ & $\pm 1.4 \%$ \\
\hline Maximum & - & $\pm 14.2 \%$ & $\pm 2.5 \%$ & $\pm 2.0 \%$ & $\pm 2.1 \%$ & $\pm 3.31 \%$ & $\pm 9.4 \%$ \\
\hline Carbo $^{1}$ & 41,000 & $\begin{array}{r}6.2 \\
\pm 0.6\end{array}$ & $\begin{array}{l}15.6 \\
\pm 0.3\end{array}$ & $\begin{array}{l}35.7 \\
\pm 0.4\end{array}$ & $\begin{array}{l}38.9 \\
\pm 0.7\end{array}$ & 100.00 & $\begin{array}{l}29.0 \\
\pm 0.5\end{array}$ \\
\hline Misteca $^{1}$ & 126,000 & $\begin{array}{r}0.94 \\
\pm 0.22\end{array}$ & $\begin{array}{r}4.2 \\
\pm 0.2\end{array}$ & $\begin{array}{l}20.6 \\
\pm 0.2\end{array}$ & $\begin{array}{l}20.6 \\
\pm 0.2\end{array}$ & 100.00 & $\begin{array}{l}30.7 \\
\pm 0.2\end{array}$ \\
\hline Costilla Peak ${ }^{2}$ & 42,100 & $\begin{array}{r}7.7 \\
\pm 1.2\end{array}$ & $\begin{array}{l}16.5 \\
\pm 0.3\end{array}$ & $\begin{array}{l}35.7 \\
\pm 0.4\end{array}$ & $\begin{array}{l}38.1 \\
\pm 0.5\end{array}$ & 100.00 & $\begin{array}{l}29.8 \\
\pm 0.2\end{array}$ \\
\hline $\mathrm{Air}^{3}$ & - & 0.62 & 3.96 & 20.21 & 20.16 & 100.00 & 30.55 \\
\hline $\operatorname{AvCC}^{4}$ & - & 0.60 & 3.92 & 20.15 & 20.17 & 100.00 & 30.98 \\
\hline
\end{tabular}

${ }^{1}$ MUNK (1967b). ${ }^{2}$ MUNK (1967a). ${ }^{3}$ NIEF (1960). ${ }^{4}$ EUGSTER et al. (1967).

accompnaied by other isotopes of $\mathrm{Kr}$ (NIEF, 1960) and Xe (NIER, 1950b) in the proportions seen in air.

The concentrations of light, spallogenic noble gases in our sample are about a factor of 2 less than the amounts that SCHAEFFER and ZäHRINGER $(1960)$ reported in one specimen of Canyon Diablo, and the concentration of spallogenic ${ }^{38} \mathrm{Ar}$ is a factor of 44 less than that reported by LÄMMERZAHL and ZÄHRINGER (1966) in another. HeYMANN et al. (1966) note that the concentrations of spallogenic ${ }^{3} \mathrm{He}$ in 56 specimens of Canyon Diablo vary by a factor of $10^{4}$. They reported spallogenic $\mathrm{He}, \mathrm{Ne}$ and $\mathrm{Ar}$ in a few gas-rich specimens, and the amounts in their most gas-rich specimen, (AML \# 34.4341) is included in Table 4. The concentrations of spallogenic gases in that specimen are about a factor of $10^{2}$ greater than in ours, i.e., the amounts of spallation products in our specimen are about midway in the range spanned by the 56 specimens of HeYManN et al. (1966).
If the wide range of spallation products in different specimens of Canyon Diablo reflect differences in shielding during exposure to cosmic rays, then these differences might be reflected in the ratio of spallation products generated by high energy (hard) and lower energy (soft) radiation. Values of the ${ }^{3} \mathrm{He} /{ }^{21} \mathrm{Ne}$, ${ }^{4} \mathrm{He} /{ }^{38} \mathrm{Ar}$ and ${ }^{21} \mathrm{Ne} /{ }^{38} \mathrm{Ar}$ ratios are widely used as monitors of sample depth within meteoroids during exposure to cosmic rays (SIGNER and NIER, 1960, 1962; NYQUIST et al., 1967, 1973; Schultz et al., 1969, 1971 and references therein). The abundances of spallogenic ${ }^{3} \mathrm{He}$ and ${ }^{4} \mathrm{He}$ relative to spallogenic $\mathrm{Ne}$ and $\mathrm{Ar}$ in our specimen of Canyon Diablo are lower than in most iron meteorites. In view of the possibility of preferential diffusive loss of $\mathrm{He}$ or tritium, the spallogenic precursor of about two-thirds of the ${ }^{3} \mathrm{He}$ (SCHULTZ et al., 1969), we will delay the discussion of spallogenic He until after a discussion of the record that ${ }^{21} \mathrm{Ne}$ and ${ }^{38} \mathrm{Ar}$ contain about our specimen's exposure to cosmic rays. 


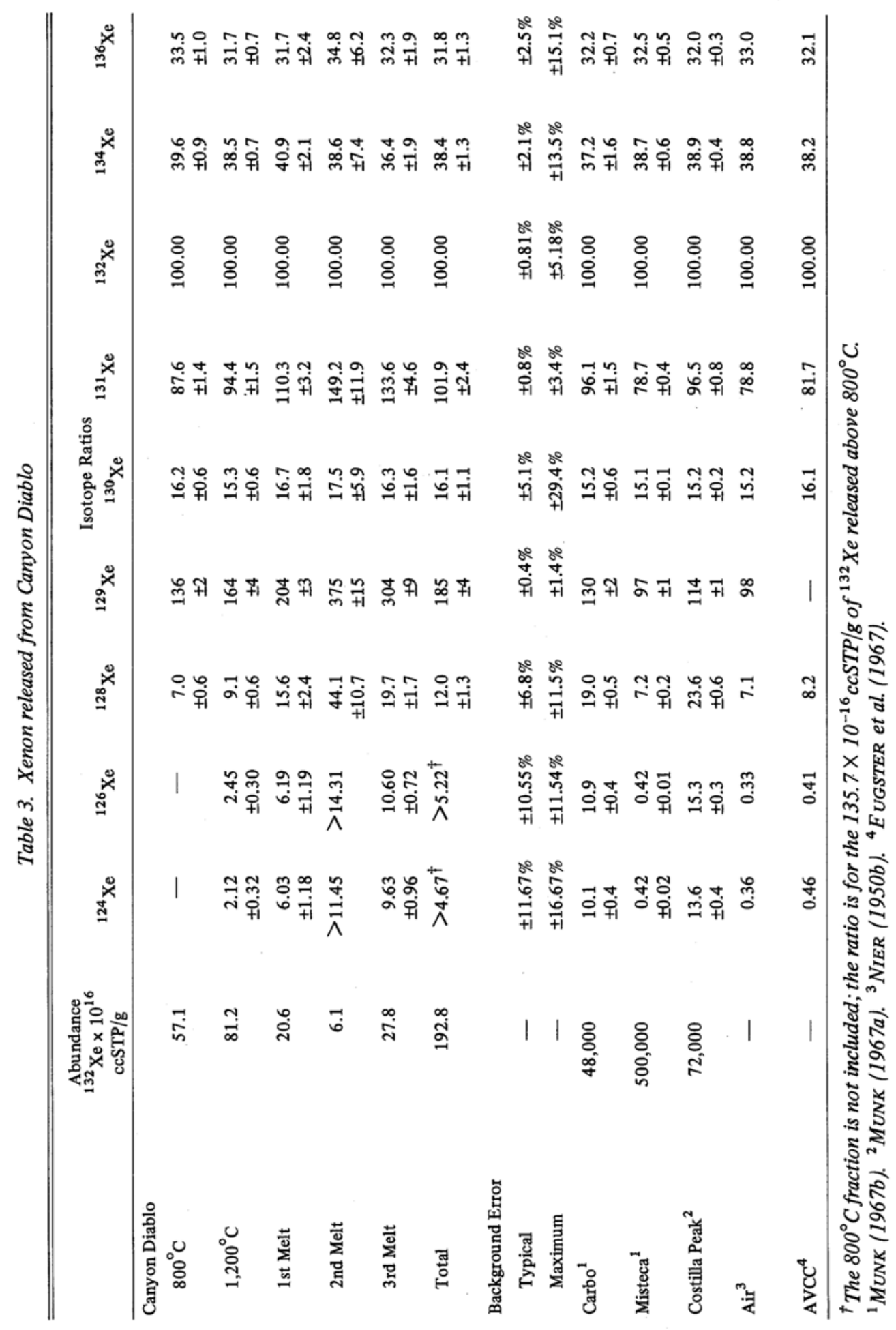







Iron and nickel are expected to be the two major target elements for the generation of spallation products when an iron meteorite is bombarded with cosmic rays. High energy irradiation will tend to increase the spallation yield of a low mass products like ${ }^{21} \mathrm{Ne}$ relative to that of a product like ${ }^{38} \mathrm{Ar}$ that is nearer to the mass of the target element. Accordingly, the ${ }^{21} \mathrm{Ne} /{ }^{38} \mathrm{Ar}$ ratio should be higher for speciments of Canyon Diablo that were near the meteoroid surface than for those that were shielded (buried) during cosmic-ray bombardment.

The value of the ${ }^{21} \mathrm{Ne} /{ }^{38} \mathrm{Ar}$ ratio for the total amount of gas released from our specimens of Canyon Diablo, 0.20 , is very similar to that seen in many earlier analyses of bulk iron meteorite samples (SIGNER and NIER, 1960, 1962; HeYmann et al., 1966; Schultz et al., 1969, 1971). However, in none of the individual gas fractions of Canyon Diablo does ${ }^{21} \mathrm{Ne} /{ }^{38} \mathrm{Ar}=$ 0.20 . This raises questions about the significance of the ${ }^{21} \mathrm{Ne} /{ }^{38} \mathrm{Ar}$ ratio for the sum of those fractions - or for gases extracted from bulk meteorite samples in a single stage.

Elemental fractionation does not seem to be a viable explanation for variations observed in values of ${ }^{21} \mathrm{Ne} /{ }^{38} \mathrm{Ar}$. We will show later that variations of ${ }^{4} \mathrm{He} /{ }^{38} \mathrm{Ar}$ and ${ }^{21} \mathrm{Ne} /{ }^{38} \mathrm{Ar}$ ratios in the gases released from Canyon Diablo are similar to those observed in mineral fractions of iron meteorites. Further, the release pattern of spallogenic $\mathrm{Kr}$ and $\mathrm{Xe}$ from Canyon Diablo more closely follows the release of ${ }^{21} \mathrm{Ne}$ than that of ${ }^{38} \mathrm{Ar}$.

SCHULTZ et al. (1971) interpret the value of the ${ }^{21} \mathrm{Ne} /{ }^{38} \mathrm{Ar}=0.20$ in bulk iron meteorites as evidence of exposure to cosmic rays with an average radiation hardness index, $\mathrm{k}=2.5$, where $\mathrm{k}$ is defined by the relationship

$$
\left({ }^{21} \mathrm{Ne} /{ }^{38} \mathrm{Ar}\right)=\left[\left(\mathrm{A}_{\circ}-38\right) /\left(\mathrm{A}_{\circ}-21\right)\right]^{\mathrm{k}}
$$

and $\mathrm{A}_{\circ}$ is the atomic number of the target element. Equation (1) is a special case of the general relationship (GEISs et al., 1962;
SCHWARZ and OESCHGER, 1967) derived earlier for the total production rate, $\mathrm{Q}$, of the isobaric products at mass number $\mathrm{A}^{\prime}$, from spallation reactions on a target element of mass number $A_{\circ}$,

$$
Q\left(A^{\prime}\right)=C\left(A_{\circ}-A^{\prime}\right)^{-k}
$$

Larger values of the $\mathrm{k}$ in Eq. (1) and Eq. (2) correspond to greater depths in the meteorite body. Accordingly, this radiation hardness index is greater for soft than for hard radiation.

HoNDA (1962) showed that the isobaric yields of spallation products in a thick iron target bombarded by $3 \mathrm{Bev}$ protons follow the relationship shown by Eq. (2) when $A_{\circ}-A^{\prime} \geqslant 6$. He notes that the values obtained for $k$ in his experiment are close to those observed in iron meteorites, ranging from $\mathrm{k}=2.1$ at the center of a $10 \mathrm{~cm}$ iron sphere to $\mathrm{k}=2.4$ at the center of a $40 \mathrm{~cm}$ one.

The values of the ${ }^{21} \mathrm{Ne} /{ }^{38} \mathrm{Ar}$ ratio in individual gas fractions of Canyon Diablo varied from 0.081 in the third fraction (1st melt fraction) to 0.59 in the fifth fraction (3rd melt fraction). The high ${ }^{21} \mathrm{Ne} /{ }^{38} \mathrm{Ar}$ ratio in the last gas fraction could not be explained by diffusive fractionation of these spallation products by stepwise gas extraction. NYQUIST et al. (1972) also note that the thermal release of spallogenic noble gases, $\mathrm{He}, \mathrm{Ne}$ and $\mathrm{Ar}$ from the Carbo iron meteorites shows virtually no fractionation.

Evidence of heterogeneities in the ${ }^{21} \mathrm{Ne} /{ }^{38} \mathrm{Ar}$ ratio in fractions of other iron meteorites that diaplay values of ${ }^{21} \mathrm{Ne} /{ }^{38} \mathrm{Ar}=0.2$ for the bulk meteorite samples are shown in Fig. 1, together with values of the ${ }^{21} \mathrm{Ne} /{ }^{38} \mathrm{Ar}$ ratio in each of Canyon Diablo's gas fractions.

The bars on the left show values of the ${ }^{21} \mathrm{Ne} /{ }^{38} \mathrm{Ar}$ ratio in the sum of the Canyon Diablo gas fractions and in bulk samples of the Odessa (Schultz et al., 1969), Toluca and Grant (SchulTz et al., 1971) iron meteorites. These three meteorites were selected for display because separated mineral phases of these meteorites have been analyzed for spallogenic noble gases. Values of the ${ }^{21} \mathrm{Ne} /{ }^{38} \mathrm{Ar}$ ratio in 
Odessa taenite (ScHUlTz et al., 1969), Toluca taenite and an acid-resistant residue of Grant containing minerals like schreibersite, graphite, cohenite and possibly silicates (ScHuLTz et al., 1971) cover the entire range of values observed in separated minerals of the seven different iron meteorites analyzed by ScHulTz et al. (1969, 1971).

Low values of the ${ }^{21} \mathrm{Ne} /{ }^{38} \mathrm{Ar}$ ratio in the gas released in the 1st, 3rd and 4th gas fractions of Canyon Diablo seem to indicate exposure to low energy radiation. Higher values of the ${ }^{21} \mathrm{Ne} /{ }^{38} \mathrm{Ar}$ ratio in the 2 nd and 5 th extractions might indicate the degassing of phases containing light target elements, such as $\mathrm{S}, \mathrm{P}$ or $\mathrm{Si}$. Spallation reactions on these light elements would generate ${ }^{21} \mathrm{Ne}$ but not ${ }^{38} \mathrm{Ar}$, thus producing higher ${ }^{21} \mathrm{Ne} /$ ${ }^{38} \mathrm{Ar}$ ratios in troilite, schreibersite or silicates than in the nickel-iron phases.

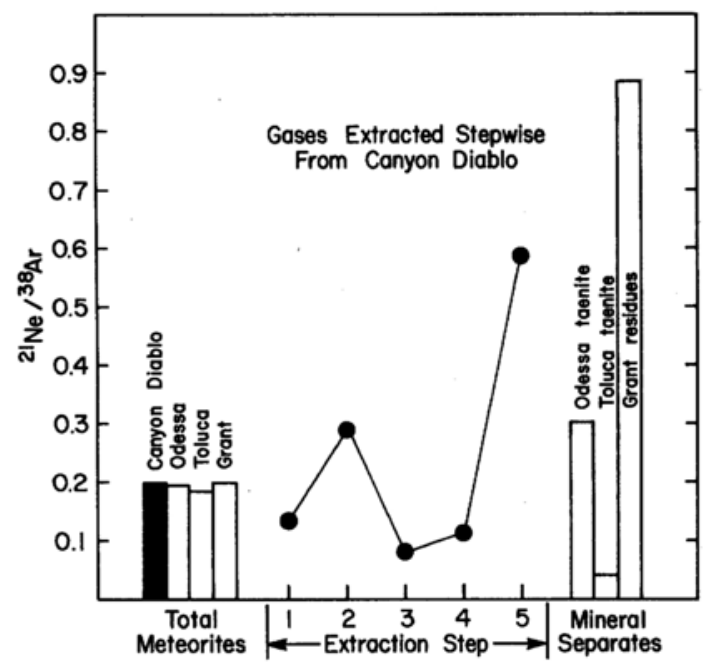

Fig. 1. Variations observed in values of the ${ }^{21} \mathrm{Ne} /{ }^{38} \mathrm{Ar}$ ratio in selected bulk samples of iron meteorites (bars on left), in their mineral separates (bars on right), and in gases released by stepwise heating of our Canyon Diablo sample (circles). The value of the ${ }^{21} \mathrm{Ne} /{ }^{38} \mathrm{Ar}$ ratio for the total gas extracted from our sample of Canyon Diablo (filled bar) is like those observed when gases are extracted from bulk samples of other iron meteorites (SCHULTZ et al., 1969; 1971). Fluctuations observed in the ${ }^{21} \mathrm{Ne} /{ }^{38} \mathrm{Ar}$ ratio in the gas fractions of Canyon Diablo lie within the range of values observed in separated mineral fractions of other iron meteorites (SCHULTZ et al., 1969; 1971).
MOORE et al. (1967) report average values of $0.8 \%$ schreibersite, $(\mathrm{Fe}, \mathrm{Ni})_{3} \mathrm{P}$, and $1.6 \%$ troilite, $\mathrm{FeS}$, in 14 "plains" specimens of Canyon Diablo. Buchwald (1975) notes that silicates are present in some samples of Canyon Diablo but not to the extent in several other Group I iron meteorites, e.g., Odessa, Campo del Cielo and Toluca. Since the melting points of schreibersite and troilite are between 800 and $1,200^{\circ} \mathrm{C}$, it is reasonable to expect that the gases extracted from Canyon Diablo at $1,200^{\circ} \mathrm{C}$ the 2nd extraction step shown in Fig. $1-$ may contain excess spallogenic ${ }^{21} \mathrm{Ne}$ from reactions on $\mathrm{P}$ and $\mathrm{S}$.

Taenite, the Ni-rich $\gamma$-phase of iron-nickel, has a lower melting temperature than kamacite, the Ni-poor $\alpha$-phase (GoldsteIN, 1973). Taenite contains appreciably less phosphorus than kamacite (REED, 1967), and it is reasonable to expect that the gases extracted from Canyon Diablo in the first melt - the 3rd extraction step shown in Fig. 1 - may be enriched in spallogenic gases that were generated by cosmic-ray irradiation of taenite.

Physical trapping of a low melting phase within a high melting phase might invalidate the gas release pattern expected solely on the basis of melting temperatures. Such action would only tend to reduce the purity of our separation of spallation components from different minerals. Thus, contamination with spallation products from light elements would tend to increase the ${ }^{21} \mathrm{Ne} /{ }^{38} \mathrm{Ar}$ ratio, and the value of the ${ }^{21} \mathrm{Ne} /$ ${ }^{38} \mathrm{Ar}$ ratio in gases released in the $3 \mathrm{rd}$ extraction step can therefore be considered to be the maximum value for the production ratio of these two spallation products in pure nickeliron. Since the atomic weight of $\mathrm{Ni}$ is greater than that of $\mathrm{Fe}$, substitution of $\mathrm{A}_{\circ}=56$ and ${ }^{21} \mathrm{Ne} /{ }^{38} \mathrm{Ar} \leqslant 0.081$ into Eq. (1) yields a minimum value for the radiation hardness index, $\mathrm{k} \geqslant$ 3.8.

This high value of $\mathrm{k}$ corresponds to a soft irradiation, as might occur if this specimen of Canyon Diablo were shielded within a large body during exposure to cosmic rays. Although this value of $\mathrm{k}$ is much higher (indicating much 
softer radiation) than any reported earlier for iron meteorite specimens, the amounts of ${ }^{21} \mathrm{Ne}$ and ${ }^{38} \mathrm{Ar}$ that ScHuLTz et al. (1971) reported in Toluca taenite correspond to a value of ${ }^{21} \mathrm{Ne} /$ ${ }^{38} \mathrm{Ar}=0.044 \pm 0.006 \leqslant 0.050$. This ratio in Eq. (1) yields a minimum value for the radiation hardness index of their Toluca specimen, $k \geqslant$ 4.5. The concentrations of spallogenic noble gases in our specimen of Canyon Diablo are about midway in the range of values observed by HeymanN et al. (1966), and even higher values for the radiation hardness index are expected for the less gas-rich specimens of Canyon Diablo.

Thus, it appears that values of the ${ }^{21} \mathrm{Ne} /{ }^{38} \mathrm{Ar}$ ratio in certain phases of Toluca and Canyon Diablo rquire exposure to radiation that was much softer than that indicated by the value of $\mathrm{k}$ computed from the ${ }^{21} \mathrm{Ne} /{ }^{38} \mathrm{Ar}$ ratio for the total gases released from bulk meteorite samples (HoNDA, 1962; SchUlTZ et al., 1971) or from the nickel-iron particles in chondrites (NYQUIST et al., 1973). The high value shown in Fig. 1 for the ${ }^{21} \mathrm{Ne} /{ }^{38} \mathrm{Ar}$ ratios in Odessa taenite (ScHulTz et al., 1969) may have been caused by impurities of schreibersite, etc. (ScHulTZ et al., 1971) and cannot be used to obtain a minimum value of $\mathrm{k}$ for the Odessa meteorite.

ScHulTz et al. (1971) noted the anomalous abundance of spallogenic noble gases in Toluca taenite, but did not assign much significance to this because of the small amounts of rare gases in this meteorite. They calculated values of $\mathrm{k}=$ 2.4 to 2.6 from values of the ${ }^{21} \mathrm{Ne} /{ }^{38} \mathrm{Ar}$ ratio in bulk samples of Carbo, Grant, Ruff's Mountain, and Toluca and concluded that these values of $\mathrm{k}$ are also valid for the taenite and residue samples from adjacent material.

Our results suggest that the exposure history of samples with only small amounts of spallogenic noble gases, e.g., Canyon Diablo and Toluca, contain a far more intricate record of the radiation than that revealed by single stage extraction of spallogenic gases from bulk meteorites. Variations in the ratios of spallogenic products within Canyon Diablo might indicate heterogeneities in the distribution of target elements, component of spallogenic gases that was generated before the meteoroid accreted, or a redistribution of spallation products within the meteorite. These alternate possible explanations will be considered below.

AleXANDer and MANuel (1968) reported large excesses of radiogenic ${ }^{129} \mathrm{Xe}$ in inclusions of Canyon Diablo and Toluca. WAsson (1970) concluded from independent evidence that Group I irons have not been molten since the silicates and metal accreted to form a body. $\mathrm{He}$ suggested that the metal and silicates may have formed by nebular processes and that the large dimensions of the $\gamma$-phase crystals may have formed by solid state diffusion, rather than by crystallization from a melt. BILD (1977) noted that the silicate inclusions of these meteorites are chondritic in mineralogy and bulk composition, and recently NIEMEYER (1979) suggested on the basis of I-Xe dating that troilite inclusions may have formed in another nebular region than that which produced the metal or silicates.

If the Group I irons in fact represent such an agglomeration of primitive material from different regions of the nebula, then part of the variation observed in ratios of spallogenic noble gases may be an indication of irradiation prior to accretion. Ex́cess spallogenic gases that cannot be explained by differences in shielding or chemical composition have been observed in a few inclusions and mineral separates of stone meteorites. These observations were attributed to a preirradiation (SCHULTZ et al., 1972; SRINIVASAN et al., 1977; SABU and MANUEL, 1980b). If different phases of an iron meteorite were exposed to different irradiations prior to accretion, then this might generate different ratios as well as differences in the total amounts of spallogenic noble gases in the different phases. Multiple exposures of meteoroids have been suggested to explain the abundances of spallogenic gases released from a few bulk meteorite samples (HeymanN et al., 1966; Voshage and FELDMAN, 1979; HeUSSER et al., 1979 and references therein).

It should be noted that ScHulTz et al. (1971) observed about 6.5 times higher con- 
centrations of spallogenic ${ }^{38} \mathrm{Ar}$ in taenite than in bulk samples of Toluca. The taenite was also enriched by a factor of 1.6 in cosmogenic ${ }^{21} \mathrm{Ne}$ relative to that in bulk Toluca. Both of these observations are unexplained by simple exposure of a compacted body to radiation, although an irradiation prior to accretion could account for both observations. Irradiation of Toluca as a body would be expected to generate higher concentrations of ${ }^{21} \mathrm{Ne}$ in the bulk meteorite than in taenite because of the high purity of nickel-iron there. Concentrations of the target elements for the production of ${ }^{38} \mathrm{Ar}$ could hardly be enriched by a factor of 6.5 in the taenite relative to that of the bulk sample. Thus, presently available data on spallogenic ${ }^{21} \mathrm{Ne}$ and ${ }^{38} \mathrm{Ar}$ in separated phases of Toluca seem to favor an irradiation before the phases were assumed.

In the case of Canyon Diablo, the bulk chemical composition of this meteorite can be used to determine whether irradiation of the bulk meteoroid can account for the variations in the ${ }^{21} \mathrm{Ne} /{ }^{38} \mathrm{Ar}$ ratio shown in Fig. 1. Schultz et al. (1971) suggest that spallation reactions on phosphorus in schreibersite may explain the high value of the ${ }^{21} \mathrm{Ne} /{ }^{38} \mathrm{Ar}$ ratio in Grant residues.

If spallation reactions on $\mathrm{Fe}$ generated all of the ${ }^{21} \mathrm{Ne}$ and ${ }^{38} \mathrm{Ar}$ in the $3 \mathrm{rd}$ gas fraction and all of the ${ }^{38} \mathrm{Ar}$ in the other gas fractions, then spallation reactions on elements lighter than iron produced a minimum of $59.1 \%$ of the total spallogenic ${ }^{21} \mathrm{Ne}$ in our sample. Although not impossible, this would require the production of $\geqslant 2.67 \times 10^{-10} \mathrm{ccSTP}{ }^{21} \mathrm{Ne} / \mathrm{g}$ from spallation reactions on elements like $\mathrm{Si}, \mathrm{P}$ or $\mathrm{S}$.

The term C in Eq. (2) is a constant for the production of one spallation product from a single target. For the production of a spallation product of mass $\mathrm{A}^{\prime}$ from two different target elements of mass $A_{\circ}$ and $A_{1}$, the relative production rates, $\mathrm{Q}\left(\mathrm{A}^{\prime}\right)_{\mathrm{A}_{0}} / \mathrm{A}\left(\mathrm{Q}^{\prime}\right)_{\mathrm{A}_{1}}$, are (SCHWARZ and Oeschger, 1967; Schultz et al., 1971)

$$
\begin{aligned}
& \mathrm{Q}\left(\mathrm{A}^{\prime}\right)_{\mathrm{A}_{\circ}} / \mathrm{Q}\left(\mathrm{A}^{\prime}\right)_{\mathrm{A}_{1}}=\left(\mathrm{A}_{\circ} / \mathrm{A}_{1}\right)^{2 / 3}[(1 \\
& \left.\left.+0.02 \mathrm{~A}_{\circ}\right) /\left(1+0.02 \mathrm{~A}_{1}\right)\right]^{\mathrm{k}-1}\left[\left(\mathrm{~A}_{\circ}\right.\right. \\
& \left.\left.\quad-\mathrm{A}^{\prime}\right) /\left(\mathrm{A}_{1}-\mathrm{A}^{\prime}\right)\right]^{-\mathrm{k}}
\end{aligned}
$$

As $\mathrm{k}$ increases, i.e., as the radiation hardness decreases, the production rate of ${ }^{21} \mathrm{Ne}$ from light elements like $P$ increases relative to the production rate of ${ }^{21} \mathrm{Ne}$ from $\mathrm{Fe}$ For example, when the radiation hardness index $(\mathrm{k})$ is $2.5, \mathrm{Eg}$. (3) yields a value of 3.4 for the production rate of ${ }^{21} \mathrm{Ne}$ from $\mathrm{P}$ relative to that from $\mathrm{Fe}$ in schreibersite, $(\mathrm{Fe})_{3} \mathrm{P}$. If instead $\mathrm{k}=3.8$, then Eq. (3) yields a value of 12.4 for this production ratio.

BuCHWALD (1975) suggests that Canyon Diablo contains $0.9-1.0 \%$ sulfur and $0.25 \pm$ $0.05 \%$ phosphorus by weight, but MOORE et al. (1967) suggest lower values for both elements. The higher values will be used to demonstrate the minimum difficulty faced in explaining the bulk value of ${ }^{21} \mathrm{Ne} /{ }^{38} \mathrm{Ar}=0.20$ in a specimen in which the production ratio of these spallation products from iron is $\leqslant 0.081$. Silicate inclusions are not common in Canyon Diablo, and since our sample was selected to avoid inclusions, it seems unlikely that we will seriously underestimate the production of ${ }^{21} \mathrm{Ne}$ from light elements by ignoring $\mathrm{Si}$ and using average estimates of Buchwald (1975) for the S and P contents.

The average content of $\mathrm{P}$ and $\mathrm{S}$ (BUCHWALD, 1975 ) in Eq. (3) yields a value ${ }^{21} \mathrm{Ne} /{ }^{38} \mathrm{Ar}=0.133$ \pm 0.005 for the total spallogenic gases in Canyon Diablo when $\mathrm{k}=3.8$, the minimum value calculated above for the radiation hardness index. The use of higher values of $\mathrm{k}$ in Eq. (1) and Eq. (3) will not generate higher values of ${ }^{21} \mathrm{Ne} /{ }^{38} \mathrm{Ar}$ and thus cannot explain the value of ${ }^{21} \mathrm{Ne} /{ }^{38} \mathrm{Ar}=$ 0.20 for the total gases in Canyon Diablo. The concentrations of light elements must be 2.3 times the estimate of Buchwald (1975) if Eq. (1) and Eq. (3) are to account for a net value ${ }^{21} \mathrm{Ne} /{ }^{38} \mathrm{Ar}=0.20$ in a specimen for which spallation reactions on pure nickel-iron generate ${ }^{21} \mathrm{Ne} /{ }^{38} \mathrm{Ar}=0.081$.

Although we cannot rule out the possibility that our sample of Canyon Diablo was enriched in light elements, this explanation for variations in the ${ }^{21} \mathrm{Ne} /{ }^{38} \mathrm{Ar}$ ratio in different gas fractions seems rather contrived. A redistribution of spallation products, rather than a heterogeneous 
distribution of target elements, might explain variations in the ${ }^{21} \mathrm{Ne} /{ }^{38} \mathrm{Ar}$ ratio, but it is difficult to imagine a natural process that would separate these two gases. Since the ${ }^{21} \mathrm{Ne} /{ }^{38} \mathrm{Ar}$ ratio for the sum of the gas fractions is "normal", the gases lost from one phase would then have been incorporated into another, i.e., the hypothetical process would have increased the ${ }^{21} \mathrm{Ne} /{ }^{38} \mathrm{Ar}$ ratio in one region by decreasing it in another. Recoil or gas diffusion might accomplish this separation, but neither of these will explain the enrichments that ScHuLTz et al. (1971) observed for the absolute concentrations of ${ }^{21} \mathrm{Ne}$ and ${ }^{38} \mathrm{Ar}$ in the taenite phase of Toluca. Thus, it seems clear that a very complex record may be concealed within the almost identical values of the ${ }^{21} \mathrm{Ne} /{ }^{38} \mathrm{Ar}$ ratio in bulk samples of iron meteorites.

The release pattern of spallogenic helium also indicates a more complicated exposure history than that revealed by the total spallogenic gases in bulk samples. The value of the ${ }^{4} \mathrm{He} /{ }^{3} \mathrm{He}$ ratio in gases released from our sample of Canyon Diablo is indistinguishable from that seen in dozens of other iron meteorites, but values of the ${ }^{3} \mathrm{He} /{ }^{38} \mathrm{Ar},{ }^{3} \mathrm{He} /{ }^{21} \mathrm{Ne},{ }^{4} \mathrm{He} /{ }^{21} \mathrm{Ne}$ and ${ }^{4} \mathrm{He} /{ }^{38} \mathrm{Ar}$ ratios for the sum of the Canyon Diablo gas fractions are below the values reported for most iron meteorites (SIGNER and NIER, 1960, 1962; HeYMANN et al., 1966; NYQUIST et al., 1967, 1972; SchulTz et al., 1969, 1971). Low values of these ratios would, by conventional views, indicate exposure to hard radiation, i.e., near the surface rather than buried in the meteoroid. Thus, the type of radiation indicated by low values of the $\mathrm{He} / \mathrm{Ne}$ and $\mathrm{He} / \mathrm{Ar}$ ratios in Canyon Diablo is opposite to that indicated by low values of the ${ }^{21} \mathrm{Ne} /{ }^{38} \mathrm{Ar}$ ratio in parts of the sample.

Values of the ${ }^{4} \mathrm{He} /{ }^{38} \mathrm{Ar}$ and ${ }^{3} \mathrm{He} /{ }^{21} \mathrm{Ne}$ ratios in gases extracted from bulk samples are widely used as monitors of sample depth during exposure to cosmic-ray bombardment (SIGNER and NiER, 1960, 1962; HeYMANN et al., 1966; NYQUisT et al., 1967, 1973, Schultz et al., 1969). For the sum of the gas fractions of Canyon Diablo, ${ }^{4} \mathrm{He} /{ }^{38} \mathrm{Ar}=47.5 \pm 7.1$ and ${ }^{3} \mathrm{He} /$
${ }^{21} \mathrm{Ne}=59.6 \pm 1.6$. These values lie on the curve constructed by SIGNER and NIER (1962) for variation in these ratios within a spherical iron meteorite, but values of both ratios are lower than those in any of the bulk iron meteorite samples analyzed by SIGNER and NIER (1962). It should be noted, however, that they observed the lowest values of these two ratios in a sample of the Negrillos iron meteorite, where ${ }^{4} \mathrm{He} /{ }^{38} \mathrm{Ar}$ $=58$ and ${ }^{3} \mathrm{He} /{ }^{21} \mathrm{Ne}=69$. Negrillos contained the lowest concentrations of spallogenic noble gases for which they could measure elemental ratios. Our sample of Canyon Diablo contains even less spallogenic gases. It is intriguing that ratios such as ${ }^{4} \mathrm{He} /{ }^{38} \mathrm{Ar}$ and ${ }^{3} \mathrm{He} /{ }^{21} \mathrm{Ne}$ even in bulk gases are lowest in samples from very large iron meteorites although low values of these ratios supposedly indicate exposure to hard radiation.

Large variations were observed in the values of both ${ }^{4} \mathrm{He} /{ }^{38} \mathrm{Ar}$ and ${ }^{3} \mathrm{He} /{ }^{21} \mathrm{Ne}$ in the gas fractions of Canyon Diablo, and the variations display a remarkable agreement with those seen in separated minerals of iron meteorites. For Canyon Diablo, the ${ }^{4} \mathrm{He} /{ }^{38} \mathrm{Ar}$ ratio displayed a low value of $29 \pm 4$ in the 3rd gas fraction the first melt fraction that we noted earlier might be rich in spallation products from taenite - and a high value of $69 \pm 10$ in the 2nd gas fraction where enriched spallation products from schreibersite and troilite are expected. Although such wide variations are not seen in the gases released from bulk samples of iron meteorites, ScHultz et al. (1971) observed a low value of ${ }^{4} \mathrm{He} /{ }^{38} \mathrm{Ar}=11 \pm 1$ in Toluca taenite and a high value of $95 \pm 3$ in Grant residues. In both Canyon Diablo and Toluca, low values of ${ }^{21} \mathrm{Ne} /{ }^{38} \mathrm{Ar}$ are accompanied by low values of ${ }^{4} \mathrm{He} /{ }^{38} \mathrm{Ar}$, and in both meteorites the gas fraction that displays these low ratios is expected to be enriched in spallation products from taenite. These observations seem inconsistent with the view that exposure to hard radiation produces high values of ${ }^{21} \mathrm{Ne} /{ }^{38} \mathrm{Ar}$ and low values of ${ }^{4} \mathrm{He} /$ ${ }^{38} \mathrm{Ar}$.

In gas fractions of Canyon Diablo, the ${ }^{3} \mathrm{He} /$ ${ }^{21} \mathrm{Ne}$ ratio varied from a low value of $14.0 \pm 0.4$ in the final gas fraction to a high of $119 \pm 3$ 
in the 4th gas fraction. SchulTZ et al. (1971) observed a low value of ${ }^{3} \mathrm{He} /{ }^{21} \mathrm{Ne}=23 \pm 2$ in residues of the Grant meteorite and a high value of $96 \pm 4$ in bulk samples of Grant and Carbo. In mineral separates of Grant and Carbo, they observed only values of ${ }^{3} \mathrm{He} /{ }^{21} \mathrm{Ne}$ that were lower than that in the bulk sample. Hence, in both Grant and Carbo there must be a mineral fraction, probably kamacite, with ${ }^{3} \mathrm{He} /{ }^{21} \mathrm{Ne}>$ 96.

Fractionation of spallogenic gases by selective loss from taenite might generate low values of ${ }^{3} \mathrm{He} /{ }^{21} \mathrm{Ne}$ and ${ }^{21} \mathrm{Ne} /{ }^{38} \mathrm{Ar}$, although NYQUIST et al. (1972) found virtually no fractionation of spallogenic gases in stepwise heating of a Carbo iron meteorite sample. Further, selective loss of lighter spallogenic gases that were generated by irradiation of a compacted meteoroid will not explain the observation of a $20 \%$ depletion of ${ }^{3} \mathrm{He}$, a $56 \%$ enrichment of ${ }^{21} \mathrm{Ne}$ and a $560 \%$ enrichment of ${ }^{38} \mathrm{Ar}$ in Toluca taenite (SchulTZ et al., 1971). Fractionation by recoil or diffusive loss of gases from small taenite grains during a preirradiation could explain these observations, and this seems to us to be the most plausible explanation.

We do not know the actual mechanisms involved, but additional data on the distribution of spallogenic gases in mineral phases of iron meteorites might elucidate the processes that produced such wide variations in the ${ }^{3} \mathrm{He} /{ }^{21} \mathrm{Ne}$ and ${ }^{3} \mathrm{He} /{ }^{38} \mathrm{Ar}$ ratios in gas fractions of Canyon Diablo.

Spallation and neutron-capture products in $\mathrm{Kr}$ and $\mathrm{Xe}$ The isotopic compositions of $\mathrm{Kr}$ and Xe released from Canyon Diablo are shown in Table 2 and Table 3, respectively. Spallation reactions have increased the relative abundances of the light isotopes in both gases, and the isotopes of Xe show an additional component of excess ${ }^{129} \mathrm{Xe}$ and ${ }^{131} \mathrm{Xe}$ - probably from neutron-capture on ${ }^{128} \mathrm{Te}$ and ${ }^{130} \mathrm{Te}$. CLARKE and THODE (1964) first observed an enrichment of the light isotopes of $\mathrm{Kr}$ in Canyon Diablo troilite, and MUNK (1967a, b) reported the only detailed studies of spallogenic $\mathrm{Kr}$ and $\mathrm{Xe}$ in iron meteorites. The results of his analyses together with the isotopic compositions of $\mathrm{Kr}$ and $\mathrm{Xe}$ in air and in average carbonaceous chondrites (AVCC), are included in Table 3 and Table 4.

Large variations were noted earlier in the ratios of spallogenic products in the light noble gases, e.g., the ${ }^{21} \mathrm{Ne} /{ }^{38} \mathrm{Ar}$ ratio shown in Fig. 1. The release pattern for spallation and neutroncapture products in the heavy noble gases follows that of ${ }^{21} \mathrm{Ne}$ better than that of ${ }^{38} \mathrm{Ar}$. As can be seen in Table 4 , the $1,200^{\circ} \mathrm{C}$ fraction and the 3rd melt fraction contain spikes of excess ${ }^{21} \mathrm{Ne},{ }^{83} \mathrm{Kr},{ }^{126} \mathrm{Xe},{ }^{129} \mathrm{Xe}$ and ${ }^{131} \mathrm{Xe}$. These spikes did not occur in the release of spallogenic ${ }^{38} \mathrm{Ar}$, which was greatest in the 1 st melt and only slightly less in the $1,200^{\circ} \mathrm{C}$ and 2 nd melt fractions.

Ratios of excess ${ }^{83} \mathrm{Kr},{ }^{126} \mathrm{Xe},{ }^{131} \mathrm{Xe}$ and ${ }^{129} \mathrm{Xe}$ relative to spallogenic ${ }^{38} \mathrm{Ar}$ are compared with values of the ${ }^{21} \mathrm{Ne} /{ }^{38} \mathrm{Ar}$ ratio in Fig. 2 . The positive slopes indicate correlated release with spallogenic ${ }^{21} \mathrm{Ne}$ rather than with spallogenic ${ }^{38} \mathrm{Ar}$. Target elements for the production of spallation and neutron-capture products in $\mathrm{Kr}$ and $\mathrm{Xe}$ are apparently enriched in minerals like schreibersite or troilite where the production rate of ${ }^{21} \mathrm{Ne}$ is enhanced. The association of these heavy spallogenic products with ${ }^{21} \mathrm{Ne}$ rather than ${ }^{38} \mathrm{Ar}$ seems to rule out simple diffusive fractionation as a viable explanation for variations observed in the ${ }^{21} \mathrm{Ne} /{ }^{38} \mathrm{Ar}$ ratios.

Except for a special component of neutroncapture products in the $800^{\circ} \mathrm{C}$ fraction, the release of excess ${ }^{131} \mathrm{Xe}$ and ${ }^{129} \mathrm{Xe}$ simulates the release of spallogenic ${ }^{83} \mathrm{Kr}$ and ${ }^{126} \mathrm{Xe}$. The solid lines in Fig. 2 represent least square fits, ignoring the excess ${ }^{129} \mathrm{Xe}$ and ${ }^{131} \mathrm{Xe}$ in the $800^{\circ} \mathrm{C}$ fraction. The correlation coefficients for these lines are $0.93,0,91,0.97$ and 0.95 for ${ }^{83} \mathrm{Kr}$, ${ }^{126} \mathrm{Xe},{ }^{129} \mathrm{Xe}$ and ${ }^{131} \mathrm{Xe}$, respectively.

The dashed lines connect the data of the 2nd melt, the $1,200^{\circ} \mathrm{C}$ fraction and the final melt to demonstrate systematic departures in the release of heavy noble gases from that of ${ }^{21} \mathrm{Ne}$ particularly in the $1,200^{\circ} \mathrm{C}$ fraction. The mineralogical association of tellurium with the target elements that produced spallogenic ${ }^{83} \mathrm{Kr}$ 
and ${ }^{126} \mathrm{Xe}$ seems a likely explanation for the coherent release of spallation and neutroncapture products in the heavy noble gases.

There are several indications that the excess ${ }^{129} \mathrm{Xe}$ and ${ }^{131} \mathrm{Xe}$ were produced by neutroncapture reactions on ${ }^{128} \mathrm{Te}$ and ${ }^{130} \mathrm{Te}$, respectively. Enrichments of these two xenon isotopes are in constant proportion, ${ }^{129} \mathrm{Xe} /{ }^{131} \mathrm{Xe}=3.8 \pm$ 0.5 , and in good agreement with the value of $3.9 \pm 0.5$ reported by BROWNE and BERMAN (1973) for the capture of neutrons with $E>$

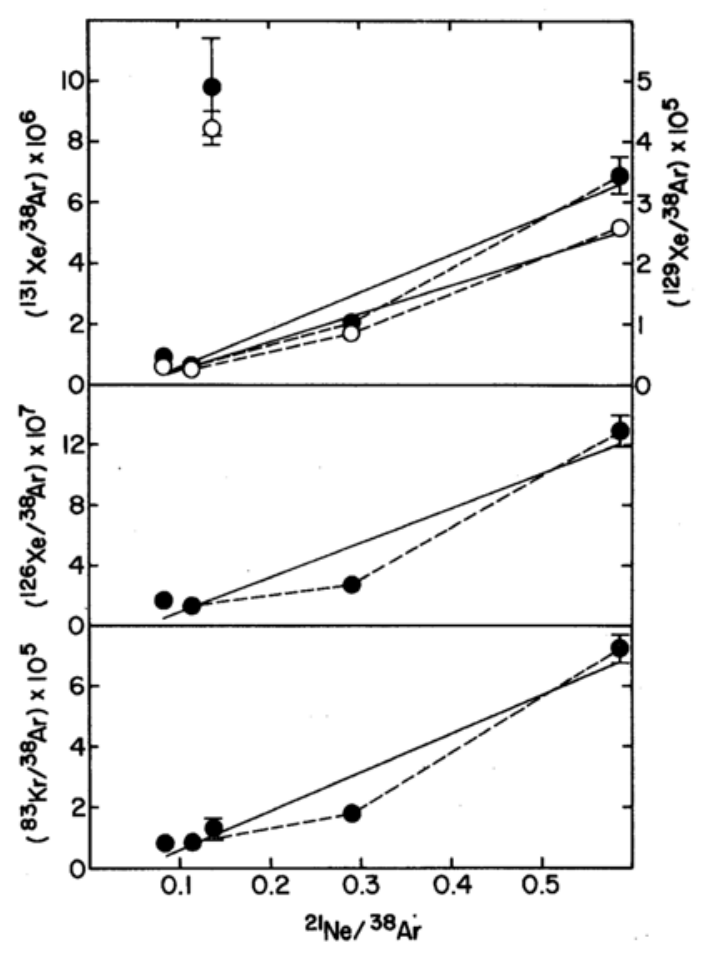

Fig. 2. The release pattern of spallation and neutroncapture products in the heavy noble gases of Canyon Diablo. The solid lines represent least squares fits to the data, and their positive slopes indicate that these heavy spallation and neutron-capture products follow spalllogenic Ne rather than Ar. Excess ${ }^{131} \mathrm{Xe}$ (filled circles) and ${ }^{129} \mathrm{Xe}$ (unfilled circles) in the $800^{\circ} \mathrm{C}$ fraction were omitted in calculating the least squares lines in the uppermost plot because of an apparent excess of neutroncapture products on ${ }^{130} \mathrm{Te}$ and ${ }^{128} \mathrm{Te}$ in this low temperature fraction. The dashed lines connecting the 2 nd melt, $1,200^{\circ} \mathrm{C}$ and $3 r d$ melt fractions demonstrate similarities in the release patterns of excess ${ }^{131} \mathrm{Xe},{ }^{129} \mathrm{Xe}$, ${ }^{126} \mathrm{Xe}$ and ${ }^{83} \mathrm{Kr}$ and systematic differences from the release of spallogenic ${ }^{21} \mathrm{Ne}$.
$0.4 \mathrm{eV}$ on ${ }^{128} \mathrm{Te}$ and ${ }^{130} \mathrm{Te}$ when the neutron flux has a $1 / \mathrm{E}$ energy dependence. Large excesses of ${ }^{129} \mathrm{Xe}$ and ${ }^{131} \mathrm{Xe}$ are observed in tellurium ores (Srinivasan et al., 1972) and the ${ }^{129} \mathrm{Xe} /{ }^{131} \mathrm{Xe}$ ratio is always intermediate to that expected from thermal-neutron capture, 0.68, and the value expected for neutron capture above $0.4 \mathrm{eV}, 3.9 \pm 0.5$.

Natural tellurium minerals have low melting points and usually release the bulk of their excess ${ }^{129} \mathrm{Xe}$ and ${ }^{131} \mathrm{Xe}$ by $800^{\circ} \mathrm{C}$ (RICHARDSON et al., 1981). Since the highest values shown in Fig. 2 for the ${ }^{131} \mathrm{Xe} /{ }^{21} \mathrm{Ne}$ and ${ }^{129} \mathrm{Xe} /{ }^{21} \mathrm{Ne}$ ratios represent gases released in the $800^{\circ} \mathrm{C}$ fraction of Canyon Diablo, this spike of neutron-capture products on $\mathrm{Te}$ without a corresponding spike of spallogenic ${ }^{21} \mathrm{Ne}$ or ${ }^{83} \mathrm{Kr}$ may indicate degassing of trace telluride minerals. Tellurium is too heavy to efficiently produce ${ }^{21} \mathrm{Ne}$ or ${ }^{83} \mathrm{Kr}$ by spallation.

The value of the ${ }^{129} \mathrm{Xe} /{ }^{131} \mathrm{Xe}$ ratio for the neutron-capture products in Canyon Diablo, $3.8 \pm 0.5$, is much higher than the value of 0.9 NIEMEYER (1979) assumed in correcting the ${ }^{129} \mathrm{Xe}$ extracted from troilite of Mundrabilla for interference from these neutron-capture products. Perhaps differences in shielding and moderation of secondary neutrons caused such divergent values in the ratio of these neutroncapture products in Canyon Diablo and Mundrabilla troilite. It should be noted that the value calculated for the ${ }^{129} \mathrm{I}-{ }^{129} \mathrm{Xe}$ age will depend on the value assumed for the ${ }^{129} \mathrm{Xe} /{ }^{131} \mathrm{Xe}$ ratio in these neutron-capture products.

Clayton (1979) has suggested that the correlation of excess ${ }^{129} \mathrm{Xe}$ with excess ${ }^{131} \mathrm{Xe}$ in Mundrabilla troilite may indicate that this contains some exotic interstellar dust grains that had trapped r-products of iodine, ${ }^{131} \mathrm{I}$ and ${ }^{129} \mathrm{I}$, in an expanding supernova shell. This struggle to find evidence in meteorites for the astrophysically attractive interstellar grains leads to the chemically improbable solution of interstellar dust causing excess ${ }^{131} \mathrm{Xe}$ and ${ }^{129} \mathrm{Xe}$ in meteoritic tellurides and neutron-capture reactions generating these same excesses in terrestrial tellurides. 
Table 5. Observed isotopic patterns for the spallogenic rare gas component in iron meteorites

\begin{tabular}{|c|c|c|c|c|c|}
\hline & Canyon Diablo ${ }^{1}$ & Canyon Diablo $^{2}$ & Misteca $^{3}$ & $\mathrm{Carbo}^{3}$ & Costilla Peak $^{3}$ \\
\hline $4 / 3$ & $\begin{array}{r}3.92 \\
\pm 0.06\end{array}$ & $\begin{array}{r}4.07 \\
\pm 0.29\end{array}$ & - & $\begin{array}{r}4.17 \\
\pm 0.07\end{array}$ & - \\
\hline $20 / 21$ & $\begin{array}{r}1.08 \\
\pm 0.02\end{array}$ & - & $\begin{array}{r}1.06 \\
\pm 0.03\end{array}$ & $\begin{array}{r}0.95 \\
\pm 0.03\end{array}$ & $\begin{array}{r}1.02 \\
\pm 0.03\end{array}$ \\
\hline $22 / 21$ & $\begin{array}{r}1.09 \\
\pm 0.02\end{array}$ & - & $\begin{array}{r}1.13 \\
\pm 0.04\end{array}$ & $\begin{array}{r}1.13 \\
\pm 0.05\end{array}$ & $\begin{array}{r}1.12 \\
\pm 0.04\end{array}$ \\
\hline $36 / 38$ & $\begin{array}{r}0.614 \\
\pm 0.002\end{array}$ & $\begin{array}{r}0.646 \\
\pm 0.029\end{array}$ & $\begin{array}{r}0.582 \\
\pm 0.015\end{array}$ & $\begin{array}{r}0.599 \\
\pm 0.018\end{array}$ & $\begin{array}{r}0.633 \\
\pm 0.015\end{array}$ \\
\hline $78 / 83$ & $\begin{array}{r}0.33 \\
\pm 0.03\end{array}$ & - & $\begin{array}{r}0.68 \\
\pm 0.58\end{array}$ & $\begin{array}{r}0.28 \\
\pm 0.03\end{array}$ & $\begin{array}{r}0.38 \\
\pm 0.07\end{array}$ \\
\hline $80 / 83$ & $\begin{array}{r}0.66 \\
\pm 0.06\end{array}$ & - & $\begin{array}{r}0.55 \\
\pm 0.44\end{array}$ & $\begin{array}{r}0.60 \\
\pm 0.04\end{array}$ & $\begin{array}{r}0.68 \\
\pm 0.02\end{array}$ \\
\hline $82 / 83$ & $\begin{array}{r}0.84 \\
\pm 0.09\end{array}$ & - & $\begin{array}{r}0.92 \\
\pm 0.64\end{array}$ & $\begin{array}{r}0.84 \\
\pm 0.06\end{array}$ & $\begin{array}{r}0.87 \\
\pm 0.03\end{array}$ \\
\hline $84 / 83$ & $\begin{array}{r}0.13 \\
\pm 0.04\end{array}$ & - & $\equiv 0$ & $\begin{array}{r}0.25 \\
\pm 0.09\end{array}$ & $\begin{array}{r}0.14 \\
\pm 0.03\end{array}$ \\
\hline $86 / 83$ & $\equiv 0$ & - & $\begin{array}{r}0.34 \\
\pm 0.38\end{array}$ & $\equiv 0$ & $\equiv 0$ \\
\hline $124 / 126$ & $\begin{array}{r}0.92 \\
\pm 0.16\end{array}$ & - & $\begin{array}{r}0.85 \\
\pm 0.27\end{array}$ & $\begin{array}{r}0.92 \\
\pm 0.06\end{array}$ & $\begin{array}{r}0.89 \\
\pm 0.03\end{array}$ \\
\hline $128 / 126$ & $\begin{array}{r}1.31 \\
\pm 0.29\end{array}$ & - & - & $\begin{array}{r}1.14 \\
\pm 0.08\end{array}$ & $\begin{array}{r}1.12 \\
\pm 0.05\end{array}$ \\
\hline $129 / 126$ & $\begin{array}{l}19.76 \\
\pm 2.91\end{array}$ & - & - & $\begin{array}{r}3.17 \\
\pm 0.38\end{array}$ & $\begin{array}{r}1.22 \\
\pm 0.08\end{array}$ \\
\hline $130 / 126$ & $\begin{array}{r}0.21 \\
\pm 0.24\end{array}$ & - & - & $\begin{array}{r}0.04 \\
\pm 0.06\end{array}$ & $\begin{array}{r}0.031 \\
\pm 0.014\end{array}$ \\
\hline $131 / 126$ & $\begin{array}{r}5.63 \\
\pm 1.09\end{array}$ & - & - & $\begin{array}{r}1.81 \\
\pm 0.27\end{array}$ & $\begin{array}{r}1.34 \\
\pm 0.08\end{array}$ \\
\hline $132 / 126$ & $\begin{array}{r}0.35 \\
\pm 0.51\end{array}$ & - & - & $\begin{array}{r}0.23 \\
\pm 0.22\end{array}$ & $\begin{array}{r}0.20 \\
\pm 0.06\end{array}$ \\
\hline $134 / 126$ & $\begin{array}{r}0.08 \\
\pm 0.36\end{array}$ & - & - & $\begin{array}{l}-0.06 \\
\pm 0.17\end{array}$ & $\begin{array}{r}0.08 \\
\pm 0.04\end{array}$ \\
\hline $136 / 126$ & $\equiv 0$ & - & $\equiv 0$ & $\equiv 0$ & $\equiv 0$ \\
\hline
\end{tabular}

${ }^{1}$ This work, $\mathrm{He}, \mathrm{Ne}, \mathrm{Ar}$, and $\mathrm{Kr}$ ratios are calculated from the 3 melt phases, Xe ratios are from the first and third melts owing to uncertainties in the ${ }^{126} \mathrm{Xe}$ abundance. ${ }^{2} \mathrm{HEYMANN}$ et al. (1966), average of 16 samples. ${ }^{3}$ MUNK (1967b), includes $\mathrm{Ne}, \mathrm{Ar}, \mathrm{Kr}$ and Xe values, NYQUIST et al. (1972) for He value.

Isotopic ratios for the spallogenic noble gases in our specimen of Canyon Diablo are compared with the results of other studies in Table 5. Although the amounts of spallogenic gases in our sample are appreciably less than those in the other samples shown in Table 5, there is generally good agreement between the values for the isotopic ratios of the spallation component.

Values of the ${ }^{129} \mathrm{Xe} /{ }^{126} \mathrm{Xe}$ and ${ }^{131} \mathrm{Xe} /{ }^{136} \mathrm{Xe}$ ratios in the spallogenic component of our samples are higher than those seen in the other iron meteorite samples. The excess ${ }^{129} \mathrm{Xe}$ and ${ }^{131} \mathrm{Xe}$ are actually neutron-capture products, but the neutron flux was presumably generated by the interaction of cosmic rays with matter. High values of the ${ }^{129} \mathrm{Xe} /{ }^{126} \mathrm{Xe}$ and ${ }^{131} \mathrm{Xe} /{ }^{126} \mathrm{Xe}$ ratios suggest either that our sample contained a higher abundance of Te relative to the target elements for the production of spallogenic ${ }^{126} \mathrm{Xe}$ or that our sample was better shielded from high energy cosmic-ray primaries and thereby exposed to radiation with a relatively large component of neutrons.

The agreement between the spallation yields for $\mathrm{Kr}$ isotopes in the different meteorites shown in Table 5 indicates that little, if any, of the excess ${ }^{83} \mathrm{Kr}$ was produced by neutroncapture on ${ }^{82} \mathrm{Se}$. The agreement between the spallation yields shown in Table 5 for Ar iso- 
topes and the constancy of the ${ }^{38} \mathrm{Ar} /{ }^{36} \mathrm{Ar}$ ratio shown in Table 1 for the high temperature fractions likewise suggest that neutron-capture on chlorine produced a negligible fraction of the $\mathrm{Ar}$ isotopes in our sample.

Trapped and fission components of the heavy gases Information on the isotopic composition of the indigenous noble gases in iron meteorites was a major objective of this investigation. The concentrations of nonspallogenic $\mathrm{Kr}$ and $\mathrm{Xe}$ in our sample of Canyon Diablo are appreciably lower than those seen in earlier analyses of iron meteorites (MUNK, 1967a, b; Hennecke and Manuel, 1977; Palma and HeymanN, 1980). The concentration of ${ }^{40} \mathrm{Ar}$ in our sample, $3.7 \times 10^{-9} \mathrm{csSTP} / \mathrm{g}$, is also appreciably lower than that reported in earlier analyses of iron meteorites.

HENNECKE and MANUEL (1977) noted that values of $\mathrm{Ar}$ isotope ratios in iron meteorites lie on the mixing line between atmospheric and spallogenic components, providing no evidence of the trapped component seen in stone meteorites with extremely low values of ${ }^{40} \mathrm{Ar} /$ ${ }^{36} \mathrm{Ar}$ (BEgEMANN et al., 1976). They suggested that the iron meteorites might have trapped a component of primitive $\mathrm{Ar}$ with atmospherictype isotopic ratios.

FISHER (1981) attempted to refute this with data obtained by stepwise extraction of Ar from the Weekeroo Station iron meteorite. He observed values of ${ }^{40} \mathrm{Ar} /{ }^{36} \mathrm{Ar}$ ranging from 7.1 to 224, lying along the mixing line noted by HenNeCKe and MANUEL (1977). The concentration of ${ }^{40} \mathrm{Ar}$ in his sample, $1 \times 10^{-5} \mathrm{ccSTP} /$ $\mathrm{g}$, is about two orders of magnitude greater than that in the samples analyzed by HENNECKE and MANUEL (1977) and about four orders of magnitude greater than that contained in our sample of Canyon Diablo. High concentrations of spallation products in his sample mask any trapped component, and we certainly agree that the large amount of ${ }^{40} \mathrm{Ar}$ that FISHER (1981) observed, and probably most of the ${ }^{40} \mathrm{Ar}$ observed by Hennecke and MANuel (1977), is atmospheric contamination:
The primitive Ar component in stone meteorites is characterized by values of ${ }^{40} \mathrm{Ar} /{ }^{36} \mathrm{Ar}=$ $2 \times 10^{-4}$ and ${ }^{38} \mathrm{Ar} /{ }^{36} \mathrm{Ar}=0.9$ (BEGEMANN et al., 1976). This component has not been observed in earlier studies of iron meteorites, and our results provide the most stringent limit for its presence in these bodies. SIGNER and NIER (1962) report the highest value of ${ }^{38} \mathrm{Ar} /{ }^{36} \mathrm{Ar}$ in sample \# S26a of the Sikhote-Alin iron meteorite. If we assume that the slightly lower ${ }^{38} \mathrm{Ar} /$ ${ }^{36} \mathrm{Ar}$ value measured in the 1 st and 2 nd melt fractions of our sample is an indication of the trapped Ar component seen in stone meteorites (BEGEMANN et al., 1976), then the maximum value for the concentration of this trapped ${ }^{36} \mathrm{Ar}$ component in Canyon Diablo is $3 \times 10^{-11}$ $\operatorname{ccSTP} / \mathrm{g}$.

Differences in values of the ${ }^{40} \mathrm{Ar} /{ }^{38} \mathrm{Ar}$ ratio in Canyon Diablo and in spallogenic Ar do not indicate the presence of a trapped component of atmospheric-type $\mathrm{Ar}$ in our sample. LÄMMERZAHL and ZÄHRINGER (1966) report values for spallation production ratios in iron meteorites of ${ }^{40} \mathrm{Ar} /{ }^{38} \mathrm{Ar}=0.186 \pm 0.005$ and ${ }^{40} \mathrm{~K} /{ }^{38} \mathrm{Ar}=0.97 \pm 0.05$. Thus, purely spallogenic argon, taking into account the possible decay of spallogenic ${ }^{40} \mathrm{~K}$, might have values of $0.181 \leqslant$ ${ }^{40} \mathrm{Ar} /{ }^{38} \mathrm{Ar} \leqslant 0.302$. Argon in the 2nd melt fraction of Canyon Diablo has a value of ${ }^{40} \mathrm{Ar} /$ ${ }^{38} \mathrm{Ar}=0.24 \pm 0.04$. Since this fraction of Canyon Diablo lies within the range of values in purely spallogenic argon, the 2 nd gas fraction provides no evidence for a trapped component of atmospheric-type Ar.

High values of ${ }^{40} \mathrm{Ar} /{ }^{36} \mathrm{Ar}$ in the $800^{\circ} \mathrm{C}$ and $1,200^{\circ} \mathrm{C}$ fractions of Canyon Diablo probably indicate atmospheric contamination, and there is a $400 \%$ uncertainty on the value of this ratio in the 3rd melt fraction. Spallation reactions have generated such a large proportion of the light noble gas isotopes in the three melt fractions that there is no clear indication of any trapped components of $\mathrm{He}, \mathrm{Ne}$ or $\mathrm{Ar}$ there.

In the case of $\mathrm{Kr}$ and $\mathrm{Xe}$, significant amounts of the nonspallogenic isotopes, e.g., ${ }^{86} \mathrm{Kr}$ and ${ }^{136} \mathrm{Xe}$, were released in each gas fraction. Variations in the relative abundances of 
other prominent isotopes, after normalizing to these spallation-shielded isotopes, can be employed to determine the isotopic compositions of $\mathrm{Kr}$ and $\mathrm{Xe}$ trapped in Canyon Diablo. These correlations are shown in Fig. 3 for $\mathrm{Kr}$ and in Fig. 4 for Xe. The isotopic compositions of $\mathrm{Kr}$ and $\mathrm{Xe}$ in Allende residue 4C57 (LEwIS et al., 1977) are shown as examples of gases that are predominantly type-X, and the isotopic compositions of these gases in air (NIER, 1950b; NIEF, 1960) and in the Kenna ureilite (WILKENING and MARTI, 1976) are shown as examples of gases that are predominantly typeY (SABU and Manuel, 1980a; Manuel and SABU, 1981).

The solid line in Figs. 3 and 4 represents a least-squares fit to the isotopic ratios of $\mathrm{Kr}$ and $\mathrm{Xe}$, respectively, in gases released from Canyon Diablo. The correlations defined by these ratios suggest that the trapped component of $\mathrm{Kr}$ and $\mathrm{Xe}$ in Canyon Diablo is primarily type-Y, rather



Fig. 3. Three isotope plot of $\mathrm{Kr}$ indicating the indigenous gas component in Canyon Diablo. A significant amount of ${ }^{86} \mathrm{Kr}$, a nonspallogenic isotope, was measured in each gas fraction of Canyon Diablo, and the least square line through the isotopic ratios of Canyon Diablo $\mathrm{Kr}$ (circles) suggests that the trapped $\mathrm{Kr}$ more nearly resembles primordial type- $Y$ than type- $X$ gas (MANUEL and $S_{A B U}, 1975$; $S_{A B U}$ and MANUEL, 1980a). Gases that are predominantly tupe-Y are shown by the triangle representing $\mathrm{Kr}$ in air (NIEF, 1960) and by the diamond representing $\mathrm{Kr}$ in the Kenna ureilite (WILKENING and MARTI, 1976). Type-X Kr is shown by the square representing $\mathrm{Kr}$ in the acid-etched residue of Allende, 4C57 (LEWIS et al., 1977). If the 800 and $1,200^{\circ} \mathrm{C}$ gas fractions are excluded in calculating the least square fit owing to possible atmospheric contamination, the line shifts further from type- $X$ gas.

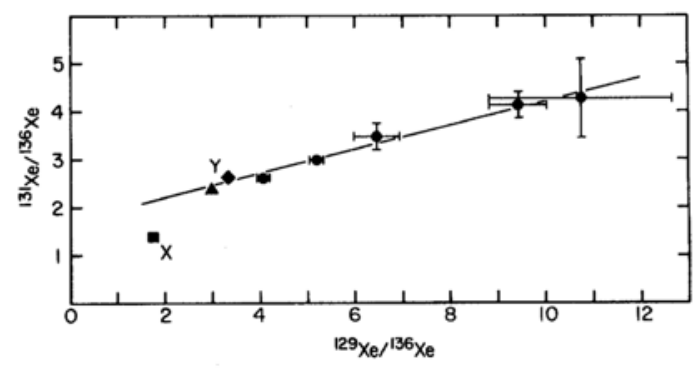

Fig. 4. Three isotope plot of Xe indicating the trapped gas component present in Canyon Diablo. As in the case of $\mathrm{Kr}$, a significant portion of the Xe released from our sample contained a component of nonspallogenic ${ }^{136} \mathrm{Xe}$. $A$ least square line fit through the isotopic ratios normalized to ${ }^{136} \mathrm{Xe}$ suggests that the trapped Xe in Canyon Diablo is similar to that in the primordial type-Y gases (MANUEL and $S_{A B U}, 1975 ; S_{A B U}$ and MANUEL, 1980a). If the 800 and $1,200^{\circ} \mathrm{C}$ gas fractions are omitted in calculating the line because of possible terrestrial contamination, the line shifts further away from the ratios seen in type- $X$ gases. As in Fig. 3, gases that are predominantly type-Y are shown by the triangle representing Xe in air (NIER, 1950b) and by the diamond representing $X e$ in the Kenna ureilite (WILKENING and MARTI, 1976). Type- $X$ gases are shown by the square representing $X e$ in the $4 C 57$ separates of the Allende meteorite (LEWIS et al., 1977).

than type-X. If ratios in the $800^{\circ} \mathrm{C}$ and $1,200^{\circ} \mathrm{C}$ fractions are discarded because of possible contamination with atmospheric gases, the correlation lines defined by the three melt fractions have slightly smaller slopes and shift further away from the isotopic ratios of type- $\mathrm{X}$ gases.

Thus, our results suggest that the $\mathrm{Kr}$ and $\mathrm{Xe}$ initially trapped in Canyon Diablo were predominantly type-Y. Since type-Y gases contain no $\mathrm{He}$ or $\mathrm{Ne}$ (SABU and Manuel, 1980a), trapped components of these two lightest noble gases are not expected in Canyon Diablo.

Recently there has been considerable discussion about the possibility that siderophilic superheavy elements (SHE) were trapped in iron meteorites (LiBBY et al., 1979; BuLL, 1979; RUNCORN et al., 1980; KAISER et al., 1981; NozetTE and Boynton, 1981). The maximum amount of excess ${ }^{136} \mathrm{Xe}$ in our sample of Canyon Diablo is 600 atoms per $\mathrm{g}$ relative to atmo- 
spheric Xe (NIER, 1950b) or 6,000 atoms per $\mathrm{g}$ relative to AVCC Xe (EUGSTER et al., 1967). These are upper limits on the number of fission events that produced fragments of mass 136 in Canyon Diablo. By comparison, recent analyses of Sm and Nd in Canyon Diablo and a few other iron meteorites have established upper limits of $10^{8}-10^{9}$ fission fragments per gram per mass number, $\mathrm{A}$, for $\mathrm{A} \approx 140-150$ (KAISER et al., 1981; NozeTte and Boynton, 1981).

The maximum amount of fission-produced ${ }^{136} \mathrm{Xe}$ in Canyon Diablo corresponds to (0.1-1) $\times 10^{-18} \mathrm{~g}$ fissiogenic ${ }^{136} \mathrm{Xe}$ per $\mathrm{g}$ Canyon Diablo. This is $12-13$ orders of magnitude less than that expected from the fission product distribution that LIBBY et al. (1979) suggested in iron meteorites.

Fission yields for SHE are not known, but the total isobar yield accumulating at ${ }^{136} \mathrm{Xe}$ is typically 3-6\% for heavy actinides (VoN GUTEN, 1966; SRINIVASAN et al., 1969, FLYNN et al., 1972a, b; SRINIVASAN and FlynN, 1980). A fission yield of $10^{-3}$ at mass 136 is therefore a conservative estimate for purposes of calculating an upper limit on the number of atoms of SHE that could have been trapped in Canyon Diablo. Accordingly, the maximum concentration of SHE that fissioned in Canyon Diablo since the onset of $\mathrm{Xe}$ retention is $6 \times 10^{6}$ atoms per $\mathrm{g}$.

\section{CONCLUSIONS}

A technique was employed for the stepwise extraction of noble gases from an iron meteorite with minimum contamination from the extraction system. The sample selected for analysis, Canyon Diablo (AML \# 34.4341), contains much smaller concentrations of spallogenic noble gases than most of the samples of iron meteorites studied earlier. Its ${ }^{3} \mathrm{He}$ content is, however, about midway in the range of values reported by HeYMANN et al. (1966) in 56 different specimens of this meteorite.

Depth variations in the distribution of spallogenic noble gases in iron meteorites have been widely reported over the past 20 years and seemed to provide unambiguous evidence for the production of these spallation products within a developed body (VINOGRADOV et al., 1957; Fireman, 1958; HofFMAN and NIER, 1958; Signer and Nier, 1960; Voshage and FeldMANN, 1970). However, variations seen in this study for ratios of spallation products within Canyon Diablo are difficult to explain by mere differences in depth or target element chemistry within the meteoroid. Preirradiation of parts of the material in Canyon Diablo is offered as a possible explanation for these observations. Variations in the ratios of spallation products in separated phases of the Toluca iron meteorite (Schultz et al., 1971) seem to support this interpretation. GERLING and LEVSKII (1958) earlier questioned simple depth variations for spallogenic gases in the Sikhote-Alin iron meteorite.

Isotopic ratios for spallogenic $\mathrm{Kr}$ and $\mathrm{Xe}$ in Canyon Diablo are in good agreement with the spallation yields reported by MuNK (1967a, b) in other iron meteorites, although larger excesses of ${ }^{129} \mathrm{Xe}$ and ${ }^{131} \mathrm{Xe}$ were observed in this study. Constancy of the ${ }^{129} \mathrm{Xe} /{ }^{131} \mathrm{Xe}$ ratios suggests that these were produced by neutron-capture on $\mathrm{Te}$, rather than by spallation, decay of primitive ${ }^{129} \mathrm{I}$, or the trapping of interstellar grains in Canyon Diablo.

The isotopic compositions of $\mathrm{Kr}$ and $\mathrm{Xe}$ released from Canyon Diablo suggest that the trapped component is predominantly the type$\mathrm{Y}$ gases seen in ureilites and in the terrestrial planets, rather than type-X gases seen in carbonrich separates of carbonaceous chondrites. Spallation products are dominant in $\mathrm{He}, \mathrm{Ne}$ and $\mathrm{Ar}$. There was no clear indication for the presence of trapped, $\mathrm{He}, \mathrm{Ne}$ or Ar. The isotopic composition of $\mathrm{Xe}$ in Canyon Diablo indicates that fission of superheavy elements have produced less than 6,000 atoms of ${ }^{136} \mathrm{Xe}$ per $\mathrm{g}$ of Canyon Diablo.

Acknowledgments-We wish to thank CINDY SONEWALD for the special effort involved in typing this manuscript, JOHN REYNOLDS for making the standard "Kaiser" gas available, and GLEN HUSS for helpful comments on the sample. The manuscript also benefited from constructive suggestions by an anonymous re- 
viewer. This research was supported by National Science Foundation Grant No. NSF EAR78 09251-01.

\section{REFERENCES}

ALEXANDER, E. C., JR. (1970) Noble gases: A record of the early solar system. Ph. D. dissertation, University of Missouri, Rolla, 64-75.

AleXANDER, E. C., JR. and MANUEL, O. K. (1968) Xenon in the inclusions of Canyon Diablo and Toluca iron meteorites. Earth Planet. Sci. Lett. 4, 113117.

ANDERS, E. A. (1981) Noble gases in meteorites: Evidence for presolar matter and superheavy elements. Proc. R. Soc. Lond. A 34, 207-238.

ARNOLD, J. R., HONDA, M. and LAL, D. (1961) Record of cosmic-ray intensity in the meteorites. $J$. Geophys. Res. 66, 3519-3531.

BEGEMANN, F., WEBER H. W. and HINTENBERGER, H. (1976) On the primordial abundance of argon40. Ap. J. 203, L155-L157.

BILD, R. W. (1977) Silicate inclusions in group IAB irons and a relation to the anomalous stones Winona and Mt. Morris (Wis.). Geochim. Cosmochim. Acta 41, 1439-1456.

BROWNE, J. C. and BERMAN, B. L. (1973) Neutron capture cross sections for ${ }^{128} \mathrm{Te}$ and ${ }^{130} \mathrm{Te}$ and the xenon anomaly in old tellurium ores. Phys. Rev. 8C, 2405-2411.

BUCHWALD, V. F. (1975) Handbook of iron meteorites. University of California Press and Arizona State University, 393-407.

BUL, R. K. (1979) A search for superheavy-element fission-tracks in iron meteorites. Nature 282, 393394.

Clarke, W. B. and ThODE, H. G. (1964) The isotopic composition of Krypton in iron meteorites. $J$. Geophys. Res. 69, 3673-3679.

Claton, D. D. (1979) Primitive troilite. Lunar Planet. Sci X. 218-220.

CRESSY, P. J., JR. and BOGARD, D. D. (1976) On the calculation of cosmic-ray exposure ages of stone meteorites. Geochim. Cosmochim. Acta 40, 749762.

EBERHARDT, P., EUGSTER, O. and MARTI, K. (1965) A redetermination of the isotopic composition of atmospheric neon. Z. Naturforsch. 20a, 623-624.

EBERT, K. H. and WANKE, H. (1957) Über die Einwirking der Höhenstrahlung auf Eisenmeteorite. $Z$. Naturforsch. 12a, 766-773.

EugSter, O., EBERHARDT, P. and GeISS, J. (1967) Krypton and xenon isotopic composition in three carbonaceous chondrites. Earth Planet. Scil. Lett. 3, 249-257.
Finkel, R. C. Kohl, C. P., Marti, K., MartineK, B., and RANCITELLI, L. (1978) The cosmic ray record of the San Juan Capistrano meteorite. Geochim. Cosmochim. Acta 42, 241-250.

FIREMAN, E. L. (1958) Distribution of helium-3 in the Carbo meteorite. Nature 181, 1725.

FISHER, D. E. (1981) A search for primordial atmospheric-like argon in an iron meteorite. Geochim. Cosmochim. Acta 45, 245-249.

FlynN, K. F., HoRwitz, E. P., BloomQuist, C. A. A., BARNES, R. F., SJOBLOM, R. K., FIELDS, P. R. and GLENDENIN, L. E. (1972a) Distribution of mass in the spontaneous fission of ${ }^{256} \mathrm{Fm}$. Phys. Rev. C 5, 1725-1729.

FlynN, K. F., SRinivasan, B., Manuel, O. K., and GLENDENIN, L. E. (1972b) Distribution of mass and charge in the spontaneous fission of ${ }^{244} \mathrm{Cm}$. Phys. Rev. C 6, 2211-2214.

FRICK, U. (1977) Anomalous krypton in the Allende meteorite. Proc. Lunar Sci Conf. 8th, 273-292.

GeISS, J., OESCHGER, H. and SCHWARZ, U. (1962) The history of cosmic radiation as revealed by isotopic changes in the meteorites and on the earth. Space Sci. Rev. 1, 197-222.

GERLING, E. K. and LeVSKII, L. K. (1958) Cosmic radiation products in the Sikhote-Alin meteorite. Doklady Akad. Nauk. USSR. 123, 420.

GoLDSTEIN, J. I. (1973) Metallography, structure and phase diagrams. In Metals handbood (eds. T. LYMANN et al.) 8th edn. 8, 304.

HENNECKE, E. W. and MANUEL, O. K. (1977) Argon, krypton and xenon in iron meteorites. Earth Planet. Sci. Lett. 36, 29-43.

HEusSER, G., KiRSTEN, T. and RIES, D. (1979) Complex irradiation history of the Kirin (H5) chondrite. Meteoritics 14, 412-414.

HeymanN, D., Lipschultz, M. E., Nielsen, B. and ANDERS, E. (1966) Canyon Diablo meteorite: Metallographic and mass spectrometric study of 56 fragments. J. Geophys. Res. 71, 619-641.

HINTENBERGER, H., SCHULTZ, L. and WEBER, H. (1969) Rare gases in the iron and in the inclusions of the Campo del Cielo meteorite, El Taco. In Meteorite research (ed. P. M. MILlMAN) Springer Verlag, Inc., New York, 895-900.

HOFFMAN, J. H. and NIER, A. O. (1958) Production of helium in iron meteorites by the action of cosmic rays. Phys. Rev. 112, 2112-2117.

HOFFMAN, J. H. and NIER, A. O. (1959) The cosmogenic ${ }^{3} \mathrm{He}$ and ${ }^{4} \mathrm{He}$ distribution in the meteorite Carbo. Geochim. Cosmochim. Acta 17, 32-36.

HONDA, M. (1962) Spallation products distributed in a thick iron target bombarded by $3-B e v$ protons. $J$. Geophys. Res. 67, 4847-4858.

KaISer, T., Piepgras, D. and Wasserburg, G. J. 
(1981) A search for evidence of a fissionable nuclide in iron meteorites and implications on heat sources in planetary cores. Earth Planet. Sci. Lett. 52, 239-250.

KIRSTEN, T. (1976) Time and the solar system. In The origin of the solar system (ed. S. F. DERMOTT) 267-272.

LÄMMERZAHL, P. and ZÄHRINGER, J. (1966) K-ArAltersbestimmungen an Eisenmeteoriten-II, Spallogenes ${ }^{40} \mathrm{Ar}$ und ${ }^{40} \mathrm{Ar}^{38} \mathrm{Ar}-\mathrm{Bestrahlungsalter}$. Geochim. Cosmochim. Acta 30, 1059-1074.

LEWIS, R. S., GRos, J. and ANDERS, E. (1977) Isotopic anomalies of noble gases in meteorites and their origins 2. Separated mineral fractions from Allende. J. Geophys. Res. 82, 779-792.

LIBBY, L. M., LIBBY, W. F., and RUNCORN, S. K. (1979) The possibility of superheavy elements in iron meteorites. Nature 278, 613-617.

LIPSCHUTZ, M. E., SIGNER, P. and ANDERS, E. (1965) Cosmic ray exposure ages of iron meteorites by the ${ }^{21} \mathrm{Ne} /{ }^{26} \mathrm{Al}$ method. J. Geophys. Res. 70, 14731489.

MAMYrin, B. A., ANUfRIEV, G. S., KAMENSKIY, I. L. and TolstikHIN, I. N. (1970) Determination of the isotopic composition of atmospheric helium. Geochim. Int. 7, 498-505.

MANUEL, O. K. and SABU, D. D. (1975) Elemental and isotopic inhomogeneities in noble gases: The case for local synthesis of the chemical elements. Trans. Mo. Acad. Sci. 9, 104-122.

MANUEL, O. K. and SABU, D. D. (1981) The noble gas record of the terrestrial planets. J. Geochem. 15, 245-267.

MoORE, C. B., BirRell, P. J. and LEWIS, C. F. (1967) Variation in the chemical and mineralogical composition of rim and plains specimens of the Canyon Diablo meteorite. Geochim. Cosmochim. Acta 31, 1885-1892.

MülleR, O., HAMPEL, W., KIRSTEN, T. and HERZOG, G. F. (1981) Cosmic-ray constancy and cosmogenic production rates in short-lived chondrites. Geochim. Cosmochim. Acta 45, 447-460.

MUNK, M. N. (1967a) Spallation neon, argon, krypton and xenon in an iron meteorite. Earth Planet. Sci. Lett. 2, 301-309.

MUNK, M. N. (1967b) Neon, argon, krypton and xenon compositions of the Misteca and Carbo iron meteorites. Earth Planet. Sci. Lett. 3, 133-138.

NIEF, G. (1960) (as reported in isctopic abundance ratios given for reference samples stocked by the National Bureau of Standards) NBS Techn. Note 51 (ed. F. MOHLER).

NIEMEYER, S. (1979) I-Xe dating of silicate and troilite from IAB iron meteorites. Geochim. Cosmochim. Acta 43, 843-860.
NIER, A. O. (1950a) A redetermination of the relative abundances of the isotopes of carbon, nitrogen, oxygen, argon and potassium. Phys. Rev. 77, 789-793.

NIER, A. O. (1950b) A redetermination of the relative abundances of the isotopes of neon, krypton, rubidium, xenon and mercury. Phys. Rev. 79, 450454.

NozeTte, S. and Boynton, W. V. (1981) Superheavy elements: An early solar system upper limit for elements 107 to 110 . Science 214, 331-333. NYQUIST, L., FUNK, H., SCHULTZ, L. and SIGNER, P. (1973) $\mathrm{He}, \mathrm{Ne}$ and $\mathrm{Ar}$ in chondritic $\mathrm{Ni}-\mathrm{Fe}$ as irradiation hardness sensors. Geochim. Cosmochim. Acta 37, 1655-1685.

NYQUIST, L. E., HUNEKE, J. C., FUNK, H. and SIGNER, P. (1972) Thermal release characteristics of spallogenic $\mathrm{He}, \mathrm{Ne}$ and $\mathrm{Ar}$ from the Carbo iron meteorite. Earth Planet. Sci. Lett. 14, 207-215.

NYQUIST, L. E., HUNEKE, J. C. and SIGNER, P. (1967) Spallogenic rare gases in the El Taco meteorite. Earth Planet. Sci. Lett. 2, 241-248.

Palma, R. L. and HeymanN, D. (1980) Isotopic anomalies of krypton and xenon in iron meteorites. Preprint, 36 pp.

Paneth, F. A. REASBECK, P. and MAYNe, K. I. (1952) Helium-3 content and age of meteorites. Geochim. Cosmochim. Acta 2, 300-303.

REED, S. J. B. (1967) The distribution of phosphorus in the Mount Edith octahedrite. Geochim. Cosmochim. Acta 31, 1969-1974.

REYNOLDS, J. H. (1956) High sensitivity mass spectrometer for noble gas analysis. Rev. Sci. Instrum. 27, 928-934.

REYNOLDS, J. H., FRICK, U., NEIL, J. M. and PHINNEY, D. L. (1978) Rare-gas rich separates from carbonaceous chondrites. Geochim. Cosmochim. Acta 42, 1775-1797.

RichaRdSON, J. F., Sinha, B., MANuel, O. K. and THORPE, R. I. (1981) Double beta-decay of ${ }^{130} \mathrm{Te}$. Submitted to Phys. Rev. C, 34 pp.

RUDSTAM, G. (1966) Systematics of spallation yields. Z. Naturforsch. 21a, 1027-1041.

RUNCORN, S. K., LIBBY, W. F. and LIBBY, L. M. (1980) Superheavy-element fission tracks in iron meteorites. Nature 287, 565.

SABU, D. D. and MANuEL, O. K. (1980a) Noble gas anomalies and synthesis of the chemical elements. Meteoritics 15, 117-138.

SABU, D. D. and MANUEL, O. K. (1980b) The neon alphabet game. Proc. Lunar Planet. Sci. Conf. 11th, 879-899.

SCHAEFFER, O. A. and Fisher, D. E. (1960) Exposure ages for iron meteorites. Nature 186, 10401042. 
SCHAFFeR, O. A. and HeYmanN, D. (1965) Comparison of ${ }^{36} \mathrm{Cl}^{36} \mathrm{Ar}$ and ${ }^{39} \mathrm{Ar}-{ }^{38} \mathrm{Ar}$ cosmic ray exposure ages of dated fall iron meteorites. J. Geophys. Res. 70, 215-224.

SCHAEFFER, O. A. and ZÄHRINGER, J. (1960 Helium, neon and argon isotopes in some iron meteorites. Geochim. Cosmochim. Acta 19, 94-99.

SCHWARZ, U. and OESCHGER, H. (1967) Spallation formula deduced from cascade and evaporation theories compared with experiments. Z. Naturforsch. 22a, 972-974.

SCHUlTZ, L., FUNK, H., NYQUIST, L. and SIGNER, P. (1971) Helium, neon and argon in separated phases of iron meteorites. Geochim. Cosmochim. Acta 35, 77-88.

SChultz, L., HuneKe, J. C., NYQUiST, L. E. and SIGNER, P. (1969) Spallogenic rare gases in taenite separated from iron meteorites. In Meteorite research (ed. P. M. MILlMAN) Springer Verlag Inc., New York, 887-897.

SChUltz, L., Signer, P., LORIN, J. C. and Pellas (1972) Complex irradiation history of the Weston chondrite. Earth Planet. Sci. Lett. 15, 403-410.

SIGNER, P. and NiER, A. O. (1960) The distribution of cosmic-ray-produced rare gases in iron meteorites. J. Geophys. Res. 65, 2947-2964.

SIGNER, P. and NIER, A. O. (1962) The measurement and interpretation of rare gas concentrations in iron meteorites. In Researches on meteorites (ed. C. B. MOORE) Wiley, 7-35.

SRINIVASAN, B., AlEXANDER, E. C., JR., and MANUEL, O. K. (1969) Xenon and krypton from the spontaneous fission of Californium-252. Phys. Rev. 179,
1166-1169.

SRINIVASAN, B., AleXANDER, E. C., JR. and ManUel, O. K. (1972) Xenon isotopes in tellurobismuthite, Boliden, Sweden. J. Inorg. Nucl. Chem. 34, 23812396.

SRINIVASAN, B. and FlynN, K. F. (1980) $\quad \mathrm{Kr}$ and Xe isotopes from spontaneous fisssion of ${ }^{248} \mathrm{Cm}$ and ${ }^{250} \mathrm{Cf}$ : Comparison with noble gases in carbonaceous chondrites. Earth Planet. Sci. Lett. 47, 235-242.

SRINIVASAN, B., Gros, J. and ANDERS, E. (1977) Noble gases in separated meteoritic minerals: Murchison (C2), Ornans (C3), Karoonda (C5) and Abee (E4). J. Geophys. Res. 82, 762-778.

WASSON, J. T. (1970) The chemical classification of iron meteorites IV, Irons with $\mathrm{Ge}$ concentrations greater than $190 \mathrm{ppm}$ and other meteorites associated with Group I. Icarus 12, 407-423.

WILKENING, L. L. and MARTI, K. (1976) Rare gases and fossil particle tracks in the Kenna ureilite. Geochim. Cosmochim. Acta 40, 1465-1473.

VINOGRADOV, A. P., ZadOROZHNYI, I. K. and FLORENSKII, K. P. (1957) Content of the inert gases in the Sikhote-Alin iron meteorite. Geokhimiya 6, 443-448.

VON GUNTEN, H. R. (1969) Distribution of mass in spontaneous and neutron-induced fission. Actinides Rev. 1, 275-298.

Voshage, H. and FeldmanN, H. (1979) Investigations on cosmic-ray-produced nuclides in iron meteorites, 3. Exposure ages, meteoroid sizes and sample depths determined by mass spectrometric analyses of potassium and rare gases. Earth Planet. Sci. Lett. 45, 293-308. 